\title{
Regional marine climate scenarios in the NE Atlantic sector close to the Spanish shores
}

\author{
Damià Gomis ${ }^{1}$, Enrique Álvarez-Fanjul ${ }^{2}$, Gabriel Jordà ${ }^{1}$, Marta Marcos ${ }^{1}$, Roland Aznar ${ }^{2}$, \\ Ernesto Rodríguez-Camino ${ }^{3}$, Juan Carlos Sánchez-Perrino ${ }^{3}$, José María Rodríguez-González ${ }^{3}$, \\ Adrián Martínez-Asensio ${ }^{1}$, Josep Llasses ${ }^{1}$, Begoña Pérez ${ }^{2}$, Marcos G. Sotillo ${ }^{2}$ \\ ${ }^{1}$ IMEDEA (Institut Mediterrani d'Estudis Avançats, Univ. de les Illes Balears - CSIC), C/ Miquel Marquès, 21, \\ 07190 Esporles, Mallorca, Spain. E-mail: damia.gomis@uib.cat \\ ${ }^{2}$ Ente Público Puertos del Estado, Avda. del Partenón, 10. 28042 Madrid, Spain. \\ ${ }^{3}$ Agencia Estatal de Meteorología, C/ Leonardo Prieto Castro, 8. 28071 Madrid, Spain.
}

\begin{abstract}
Summary: We present an overview of the changes expected during the 21 st century in key marine parameters (sea surface temperature, sea surface salinity, sea level and waves) in the sector of the NE Atlantic Ocean close to the Spanish shores. Under the A1B scenario, open-sea surface temperatures would increase by $1^{\circ} \mathrm{C}$ to $1.5^{\circ} \mathrm{C}$ by 2050 as a consequence of global ocean warming. Near the continental margin, however, the global temperature rise would be counteracted by an enhancement of the seasonal upwelling. Sea surface salinity is likely to decrease in the future, mainly due to the advection of high-latitude fresher waters from ice melting. Mean sea level rise has been quantified as $15-20 \mathrm{~cm}$ by 2050 , but two contributions not accounted for by our models must be added: the mass redistribution derived from changes in the large-scale circulation (which in the NE Atlantic may be as large as $15 \mathrm{~cm}$ in 2050 or $35 \mathrm{~cm}$ by 2100) and the increase in the ocean mass content due to the melting of continental ice (for which estimates are still uncertain). The meteorological tide shows very small changes, and therefore extreme sea levels would be higher in the 21 st century, but mostly due to the increase in mean sea level, not to an increase in the storminess. The wave projections point towards slightly smaller significant wave heights, but the changes projected are of the same order as the natural variability.
\end{abstract}

Keywords: climate change; surface temperature; surface salinity; sea level, waves.

Escenarios climáticos marinos regionalizados en el sector NE del Océano Atlántico cercano a las costas españolas

Resumen: En este trabajo se presenta una visión de conjunto de los cambios esperados en el siglo XXI en los principales parámetros marinos (temperatura y salinidad superficiales, nivel del mar y oleaje) en el sector NE del Océano Atlántico más cercano a las costas españolas. Bajo el escenario A1B, se prevé que la temperatura superficial en mar abierto suba del orden de $1-1.5^{\circ} \mathrm{C}$ para el año 2050 , como consecuencia del calentamiento global del océano. Cerca del margen continental, sin embargo, el aumento de la temperatura superficial podría ser contrarrestado por un aumento del afloramiento estacional. La salinidad superficial es probable que disminuya en el futuro, debido principalmente a la advección desde latitudes más altas de aguas provenientes de la fusión de hielos polares. El aumento del nivel del mar obtenido de los modelos se ha cuantificado en 15 a $20 \mathrm{~cm}$ para el año 2050, pero esa estima no incluye dos contribuciones adicionales que deben ser añadidas: la redistribución de masa derivada de los cambios en la circulación a gran escala (que en el Atlántico NE se ha estimado en unos 15 cm para 2050 i en $35 \mathrm{~cm}$ para 2100) y el aumento de masa debido a la fusión de hielos continentales (para el cual las estimas son todavía inciertas). La marea meteorológica muestra cambios muy pequeños, y por tanto el aumento de los niveles extremos del mar en el siglo XXI serán debidos principalmente al aumento del nivel medio, no a un aumento en la intensidad de las tormentas. Las proyecciones de oleaje apuntan a olas de altura significante ligeramente más pequeñas; de todos modos, los cambios proyectados son del mismo orden que la variabilidad natural.

Palabras clave: cambio climático; temperatura superficial; salinidad superficial; nivel del mar; oleaje.

Citation/Como citar este artículo: Gomis D., Álvarez-Fanjul E., Jordà G., Marcos M., Aznar R., Rodríguez-Camino E., Sánchez-Perrino J.C., Rodríguez-González J.M., Martínez-Asensio A., Llasses J., Pérez B., Sotillo M.G. 2016. Regional marine climate scenarios in the NE Atlantic sector close to the Spanish shores. Sci. Mar. 80S1: 215-234. doi: http://dx.doi. org/10.3989/scimar.04328.07A

Editor: J.L. Pelegrí.

Received: July 31, 2015. Accepted: November 11, 2015. Published: September 30, 2016.

Copyright: (C) 2016 CSIC. This is an open-access article distributed under the terms of the Creative Commons Attribution (CC-by) Spain 3.0 License. 


\section{INTRODUCTION}

The largest coordinated experiment using atmosphere-ocean models aimed to gain insight into the effects of emissions of greenhouse gases and aerosols on global climate is the Coupled Model Intercomparison Project (CMIP, http://cmip-pcmdi.llnl. gov/), sponsored by the World Climate Research Programme (WCRP, http://wcrp-climate.org/). The results of the simulations carried out in this project constitute the nucleus of the reports issued by the Intergovernmental Panel on Climate Change (IPCC 2013). Although these models represent today the most powerful tool for the study of past and future global climate, their applicability at regional scale is limited by their coarse resolution. In the case of the Spanish shores, for instance, global climate models (GCMs) can solve the main physical processes of the Atlantic Ocean and thus correctly reflect the large-scale hydrodynamics, but they are unable to account for regional processes such as the seasonal upwelling, the exchanges with the Mediterranean basin or the impact of regional winds on extreme sea level and waves. The study of these processes requires the use of ocean regional climate models (ORCMs) forced with a high-resolution atmospheric forcing and nested to global models at the open boundaries.

Here we present a set of regional marine climate scenarios covering the sector of the NE Atlantic Ocean surrounding the Spanish coasts. They were generated in the framework of two projects (see the Acknowledgements for their references) aimed at understanding the processes underlying the projected changes and generating useful products for coastal managers, harbour authorities and other stakeholders. The parameters dealt with are those of primary interest for impact studies on coastal ecosystems and infrastructures: sea surface temperature (SST), sea surface salinity (SSS), mean and extreme sea level and mean and extreme waves.

Given the broad scope of the work, we have focused on outlining the most important features for each of the examined parameters (e.g. mean values and trends observed during the last decades of the 20th century and trends projected for the 21 st century). These results will be compared with previous works in the discussion section, where a proper set of references will be quoted. The main processes underlying the major projected changes will also be dealt with in the discussion; however, a complete, in-depth analysis is beyond the scope of this work and would need several, more specific papers.

The structure of the paper is as follows. We first present methodological details such as the types of simulations, the characteristics of the models, the downscaling of atmospheric fields used to force the ORCMs and how the results were analysed for each variable. The next four sections are devoted to presenting the results for SST, SSS, sea level and waves. Last, all the results are discussed and the conclusions are outlined in separate sections.

\section{METHODOLOGY}

\section{Types of simulation and ocean models}

Three types of numerical simulations were carried out to obtain the set of marine regional climate scenarios presented in this work. Each type was implemented in the three characteristic 'modes' of climate studies: a hindcast mode and a control simulation for the present climate and a projection mode for the future climate.

First, we conducted baroclinic runs with an ORCM to obtain the hydrodynamic variables (temperature, salinity and currents); also the baroclinic component of sea level changes (those resulting from changes in the density of the water column and circulation) can be inferred from baroclinic simulations. The ORCM used was IBMED12, a regional implementation of the filtered free surface (non-tidal) NEMO v3.2 model (see e.g. Madec 2008, Lebeaupin-Brossier et al. 2011). The domain of IBMED12 ranged from $23^{\circ} \mathrm{N}$ to $50^{\circ} \mathrm{N}$ and from $38^{\circ} \mathrm{E}$ to $21^{\circ} \mathrm{W}$ (Fig. 1A) with a resolution of $1 / 12$ degree (i.e. it covers all the Iberian coasts, the Canary Islands and the entire Mediterranean Sea, although the latter is not discussed here). At Gibraltar, the grid is tilted and stretched in order to better follow the SW-NE axis of the real strait and to locally increase the spatial resolution (up to $6 \mathrm{~km}$ ). Even so, the model cannot reproduce all the processes occurring at the strait, so it also includes an enhanced vertical mixing parameterization aimed at mimicking the interaction between topography and tides. This combination has shown to produce reasonable results in the representation of the fluxes and water mass properties at the Strait (SotoNavarro et al. 2014, Adloff et al. 2015).

The baroclinic model was forced at surface with momentum, heat and fresh water fluxes using the formulation described by Barnier (1998). The forcing fields were obtained from the dynamic downscaling of atmospheric reanalyses for the present climate, and from the dynamic downscaling of two GCMs for the control simulations and projections (see next section for details on the downscaling process, the reanalyses and the GCMs). The temperature and salinity prescribed at the Atlantic open boundary were obtained from the Levitus-94 database (Levitus et al. 1994, Levitus and Boyer 1994) for the present climate simulations; for the projections we used the Levitus-94 database corrected with the anomalies with respect to the control run produced by the ocean module of the GCMs. In both cases we set a sponge region of $2^{\circ}$ around the boundaries where a gradual relaxation (10 to 90 days) of temperature and salinity towards the boundary values was imposed. Finally, a monthly climatology with the run-off of 40 rivers was also used as lateral freshwater input for the hindcast and control runs: the rivers of the Mediterranean Sea were obtained from the RivDis climatology (Vörösmarty et al. 1998), while the Atlantic rivers were taken from the ORCA12 model configuration (Bourdallé-Badie and Treguier 2006). For the future projections the monthly climatology of each river was corrected with the hydrological projections used in the GCM runs. Monthly mean output val- 

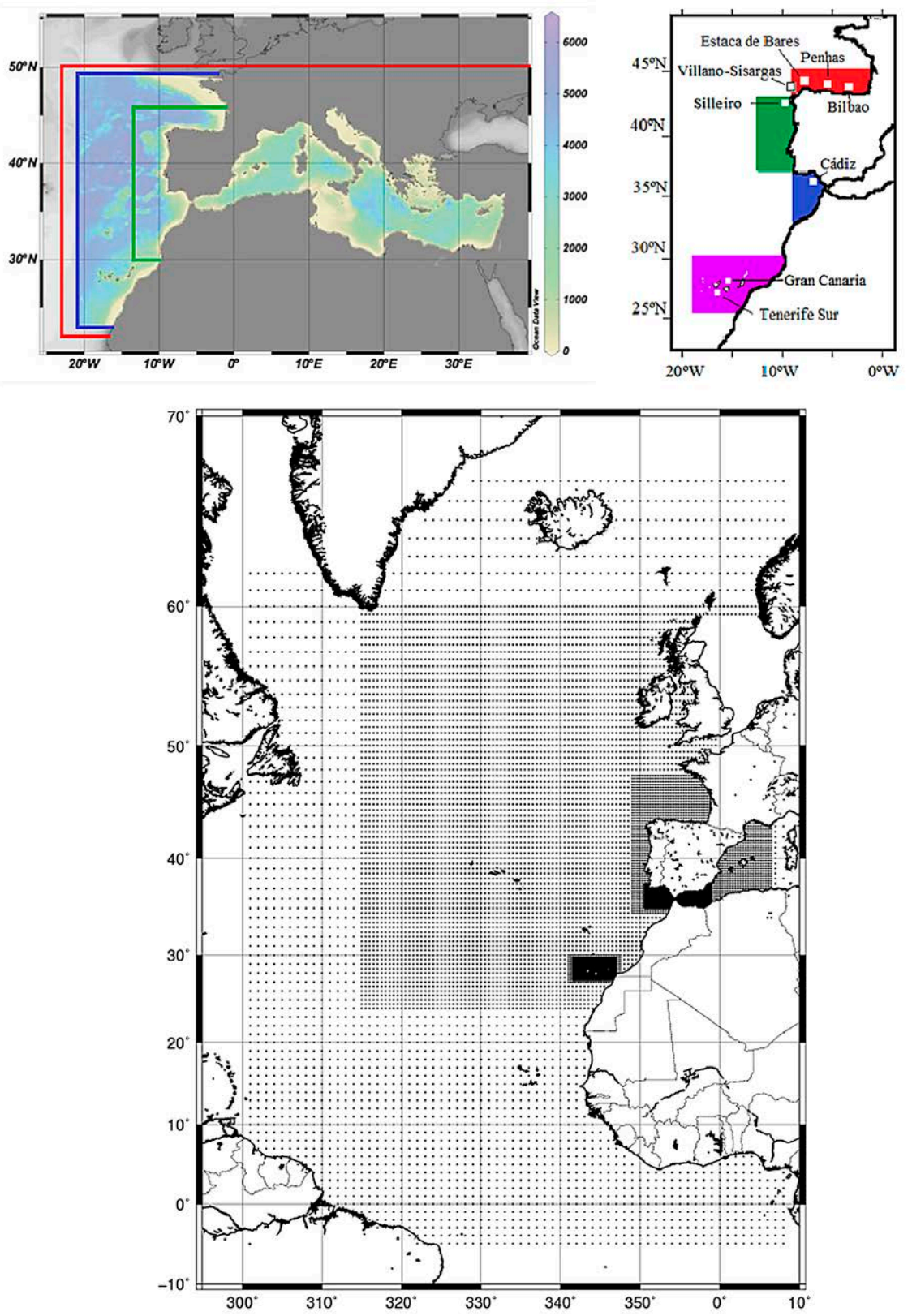

Fig. 1. - A, domains of the atmospheric downscalings used to force the ocean models (in red), of the baroclinic simulations (in blue) and of the barotropic simulations (in green). The bathymetry of the region is also plotted. B, domains selected for the regional analysis: Cantabrian Sea (red), Atlantic margin (green), Gulf of Cádiz (blue) and Canary Islands (purple). The location of the buoys used for the validation of different hindcasts is also shown. $\mathrm{C}$, domain of the wave model WAM, with the different spatial resolutions.

ues were used to obtain most of the results of this work (for some validation tests against observations we used daily values).

ORCMs rarely include atmospheric pressure among the forcing parameters. This means that the mechanical forcing of the atmosphere on sea level (the so called 'meteorological tide' or 'meteorological residuals') has to be computed separately using barotropic models. The model used here was a $2 \mathrm{D}$ version of the HAMSOM model (Backhaus 1985) implemented over the same domain used by the operational sea level forecasting service of the State-owned Spanish Port Authority (see Alvarez-Fanjul et al. 2001, and Jordà et al. 2012, for more details on its implementation). The domain covers the Mediterranean Sea and the Iberian Atlantic coasts, but not the Canary Islands (see Fig. 1A), with a spatial resolution of $1 / 4^{\circ}$ in longitude and $1 / 6^{\circ}$ in latitude $(\sim 18 \times 18 \mathrm{~km})$. The model was forced with highfrequency $(1 \mathrm{~h})$ sea level pressure and 10-m wind fields obtained from the same dynamic downscalings used to force the baroclinic runs. The use of a high-frequency forcing is crucial to resolve not only the mean regime but also the extreme values of the meteorological tide, which is the major subinertial component of sea level extremes (i.e. excluding tides, which are assumed to remain constant in time and are predictable). For the baroclinic runs we used monthly mean values to analyse the mean regime (except for some validation tests against observations). For the analysis of extremes we used hourly output values. 
Finally, wave simulations were carried out with the Wave Prediction Model (WAM), a third-generation model that explicitly solves the wave transport equation (WAMDI 1988, Günther et al. 1992). The implementation domain covered almost the entire North Atlantic in order to account for the remote forcing. The spatial resolution over the Atlantic domain ranges from $1^{\circ}$ in the outer domain to $2.5 \mathrm{~km}$ near the coasts (Fig. 1C). The model was forced with high frequency $(1 \mathrm{~h}), 10-\mathrm{m}$ wind fields from the same dynamic downscalings used to force the baroclinic and barotropic runs. Again, the use of high-frequency forcing is crucial for resolving not only the mean wave regime but also the extreme events, which are of great interest for impact studies. On output we stored significant wave height ( $\mathrm{SWH}$, the only parameter explored here), wave direction, mean period and peak period every 3 hours, though for the analysis of the mean regime we used monthly mean values. More details of these simulations can be found in Martínez-Asensio et al. (2015a, b).

\section{The atmospheric forcing}

All atmospheric fields requested to force the ocean models were obtained from regional dynamic downscalings. These were carried out with the RCA3.5 model, an atmospheric RCM developed from the HIRLAM model and initially intended for numerical weather prediction (Jones et al. 2004, Samuelsson et al. 2011). Its dynamic core uses a semi-implicit and semi-Lagrangian scheme with sixth-order horizontal diffusion applied to the predictor variables and two levels in time. The solution in the interior domain is relaxed towards the boundary conditions in a buffer zone of eight grid points using a relaxation function based on harmonics. In this study the model was configured with $0.22^{\circ}(\sim 25 \mathrm{~km})$ of spatial resolution over a domain from $22.5^{\circ} \mathrm{N}$ to $50.22^{\circ} \mathrm{N}$ and from $21.96^{\circ} \mathrm{W}$ to $42.72^{\circ} \mathrm{E}$ (Fig. $1 \mathrm{~A}$ ); in this way the boundaries of the downscaling domain are far enough from the Iberian Peninsula to avoid undesired boundary effects in the region of interest.

The RCA3.5 model was first used to downscale two atmospheric reanalyses: ERA40 (1958-2001) and ERAInterim (1989-2008), both generated by the European Centre for Medium Weather Prediction and having a temporal resolution of 6 hours. These reanalyses have been widely used among the scientific community and their details are given in many previous works (see e.g. the original papers by Uppala et al. 2005, and Dee et al. 2011). Here we will focus mainly on the downscaling of ERA40, since it covers four decades and therefore gives a more robust characterization of the present climate. ERA-Interim will be used when only recent observations are available for the validation, as is the case of buoy data.

The RCA3.5 model was also used to downscale the control simulations (1950-2000) and the future projections (2000-2100) of two state-of-the-art GCMs: ECHAM5 (referred to simply as 'ECHAM'), from the Max Planck Institute in Germany (see e.g. Roeckner et al. 2003), and HADCM3, from the Hadley Centre
Table 1. - List of runs covering the Atlantic Spanish shores.

\begin{tabular}{lcl}
\hline \multicolumn{1}{c}{ Run type } & Period & \multicolumn{1}{c}{ Forcing } \\
\hline Baroclinic ocean model runs & \\
Hindcast & $1960-2000$ & $1 \mathrm{~h}$. Downscaling of ERA-40 \\
Hindcast & $1989-2004$ & $1 \mathrm{~h}$. Downscaling of ERA-Interim \\
Control & $1961-2000$ & $1 \mathrm{~h}$. Downscaling of ECHAM5 \\
Control & $1961-2000$ & $1 \mathrm{~h}$. Downscaling of HadCM3-low \\
Projection A1B & $2001-2050$ & $1 \mathrm{~h}$. Downscaling of ECHAM5 \\
Projection A1B & $2001-2050$ & $1 \mathrm{~h}$. Downscaling of HadCM3-low \\
Barotropic ocean model runs / Wave model runs \\
Hindcast & $1958-2001$ & 1h. Downscaling of ERA40 \\
Hindcast & $1989-2008$ & 1h. Downscaling of ERA-Interim \\
Control & $1950-2000$ & 1h. Downscaling of ECHAM5 \\
Control & $1950-2000$ & 1h. Downscaling of HadCM3-low \\
Control & $1950-2000$ & 1h. Downscaling of HadCM3-ref \\
Control & $1950-2000$ & 1h. Downscaling of HadCM3-high \\
Projection A1B & $2001-2100$ & 1h. Downscaling of ECHAM5 \\
Projection A1B & $2001-2100$ & 1h. Downscaling of HadCM3-low \\
Projection A1B & $2001-2100$ & 1h. Downscaling of HadCM3-ref \\
Projection A1B & $2001-2100$ & 1h. Downscaling of HadCM3-high \\
\hline
\end{tabular}

in the UK (see e.g. Pope et al. 2000). The second was used in three different versions corresponding to different sensitivities to the anthropogenic forcing of greenhouse gases, referred to as 'HADLEY-low', 'HADLEY-ref' and 'HADLEY-high'. Of the set of available ECHAM5 and HADCM3 runs we downscaled those forced under the CMIP3 intermediate scenario $\mathrm{A} 1 \mathrm{~B}$, which assumes a rapid increase in global $\mathrm{CO}_{2}$ emissions during the first half of the 21st century to reach a peak around 2050 and decline thereafter. The more recent RCP scenarios proposed in CMIP5 differ from the SRES CMIP3 scenarios in that they focus on $\mathrm{CO}_{2}$ concentrations instead of on $\mathrm{CO}_{2}$ emissions; in practice, however, the radiative forcing of SRES and RCP scenarios is fairly similar (RCP8.5 is similar to A2, RCP6.0 to A1B and RCP1.3 to B1). Although all results obtained with the RCMs correspond to scenario A1B, we will briefly discuss their sensitivity with respect to the emission scenario basing on the results obtained with GCMs.

Finally, we must note that the whole set of downscaled control simulations and projections (ECHAM, HADLEY-low, HADLEY-ref and HADLEY-high) has only been used to force the barotropic and wave models. Because of their high computational cost, the baroclinic models have only been forced with the control simulations of ECHAM and HADLEY-low for the period 1961-2000 and with the projections of ECHAM and HADLEY-low for the period 2000-2050. It is also worth noting that a large part of the domain used to run the wave model (Fig. 1C) is not covered by the downscaling domain; in those areas (the outer part of the domain, needed to account for the remote generation of waves) the forcing winds were obtained from non-downscaled reanalysis and GCM simulations. The list of all the simulations used in this work is presented in Table 1.

\section{Analysis of results}

Results are presented in separate sections for SST, SSS, sea level and waves. For each variable the hindcast runs are first validated against observations. The objective is to assess the extent to which ocean models are able to reproduce the actual ocean variability when 
they are forced with the best approach available for the atmospheric fields (the downscaled reanalyses). If the results are considered satisfactory then the mean values and trends computed from these runs will in principle constitute a good approach to the marine climate of the last decades of the 20th century.

In a second step the hindcast and the control simulations are compared. Since the control simulation runs freely, only constrained by the radiative forcing, it cannot be expected to reproduce the chronology of the hindcast, but it should be statistically consistent with it. Parameters such as mean values and intra-seasonal, seasonal and interannual variability should be similar in both simulations (though not necessarily the same in a strict sense, since these parameters are affected by the interdecadal variability when they are averaged over a few decades). The main objective of the comparison is to assess the model ability to produce a climate realization when running in a free mode. If there were significant discrepancies between the control and the hindcast this would reveal some model deficiency and would prevent its use for future projections. Conversely, if the comparison hindcast-control is acceptable, then there is some confidence that by extending the control run to the 21 st century a realistic realization of the future climate will be obtained.

Finally, the comparison between the control and projection runs will reflect the climate impact of a greenhouse gas increase, as these two simulations only differ in that parameter. The description of the impact will be presented in different ways: by comparing the mean values of recent decades with those obtained for the 21 st century, by computing linear trends and, in the case of sea level and waves, by also comparing the extreme values.

\section{SEA SURFACE TEMPERATURE}

\section{Validation of the hindcasts and comparison with the control simulations}

In order to validate the hindcasts they have first been compared with the monthly Ishii database (Ishii and Kimoto 2009), one of the reference climatological global products. In terms of bias, the two hindcasts slightly overestimate the climatological SST in the Bay of Biscay, particularly along the Cantabrian coast (Fig. $\mathrm{S} 1$ shows the comparison for ERA40). Conversely, in the southern half of the domain the hindcasts show a slight underestimation, more pronounced along the coastal areas of Portugal and Morocco. We also compared the standard deviation, which accounts for the temporal variability at scales longer than one month; this is slightly higher for the hindcasts than for the climatology over most of the domain, particularly in the Cantabrian Sea and in the Gulf of Cádiz. The exceptions are the Atlantic Iberian coasts and the Moroccan coasts, where the variability of the hindcast is smaller than the variability of the climatology (Fig. S1).

The coastal pattern of the differences found for the standard deviation and, to a lesser extent, for the mean fields, could suggest some problems of the hindcast to capture the seasonal upwelling taking place along the African and Iberian margins. To interpret the differences correctly, one must keep in mind that the seasonal upwelling peaks in summer, making the seasonal variability of SST along the coast to be lower than in the open sea. Therefore, the underestimation of both the mean values and the variability along the coast would point towards an overestimation of the upwelling by the hindcasts. However, the alternative explanation must also be considered: it could well be that the Ishii product cannot properly resolve the upwelling pattern due to its poor resolution $\left(1^{\circ}\right)$, which would result in an overestimation of both the mean value and the standard deviation by the climatology.

Solving this issue is crucial for the reliability of the projections regarding the coastal seasonal upwelling. Therefore, the hindcasts were also validated against local SST time series from buoys (see Fig. 1B for the location of the buoys). The comparison against the buoy of Cabo Silleiro, deployed in the northern sector of the Iberian margin, within the upwelling region, is very satisfactory (Fig. S2): the bias is small $\left(-0.19^{\circ} \mathrm{C}\right.$ for ERA40, $+0.10^{\circ} \mathrm{C}$ for ERA-Interim) and also the variability is rather accurate (RMS errors $<1^{\circ} \mathrm{C}$, correlation $>0.9$ ). Beyond the statistics, the time series shown in Figure S2 confirm that the hindcasts reproduce quite well the seasonal upwelling, which shows up as a lowering of SST in summer. This suggests that the coastal differences between the hindcast and the Ishii climatology come more from the limitations of the latter than from a bad representation of the upwelling in the former.

The comparisons with other buoys (not shown) are consistent with the validation against the Ishii product shown in Figure S1. Overall, the validation supports the hindcasts as a good approximation to the truth, which encourages a more detailed characterization of the domain through the regional averaging of parameters such as the mean value, the standard deviation, the $95^{\text {th }}$ percentile or the trend (Table 2). A feature worth noting is that the trends computed for the last decades of the 20th century (1961-2000) are all positive, but they are only statistically significant around the Canary Islands $\left(0.2^{\circ} \mathrm{C} /\right.$ decade $)$.

Table 2. - Mean value, standard deviation, 95th percentile and trend of SST obtained from the hindcast forced with ERA40 (1961-2000) and averaged over the regions of Figure 1B. Trends marked with (*) are not statistically significant at the $95 \%$ confidence level.

\begin{tabular}{|c|c|c|c|c|}
\hline $\begin{array}{l}\text { SST } \\
\text { ERA-40 hindcast }\end{array}$ & Mean value $\left({ }^{\circ} \mathrm{C}\right)$ & $\operatorname{Std}\left({ }^{\circ} \mathrm{C}\right)$ & $95^{\text {th }}$ percentile $\left({ }^{\circ} \mathrm{C}\right)$ & $1961-2000$ trend $\left({ }^{\circ} \mathrm{C} /\right.$ decade $)$ \\
\hline Cantabrian Sea & 16.04 & 3.46 & 22.97 & $+0.01(*)$ \\
\hline Atlantic margin & 16.27 & 2.20 & 21.31 & $+0.01(*)$ \\
\hline Gulf of Cádiz & 18.85 & 2.74 & 24.59 & $+0.00(*)$ \\
\hline Canary Islands & 19.77 & 1.66 & 23.24 & +0.19 \\
\hline
\end{tabular}




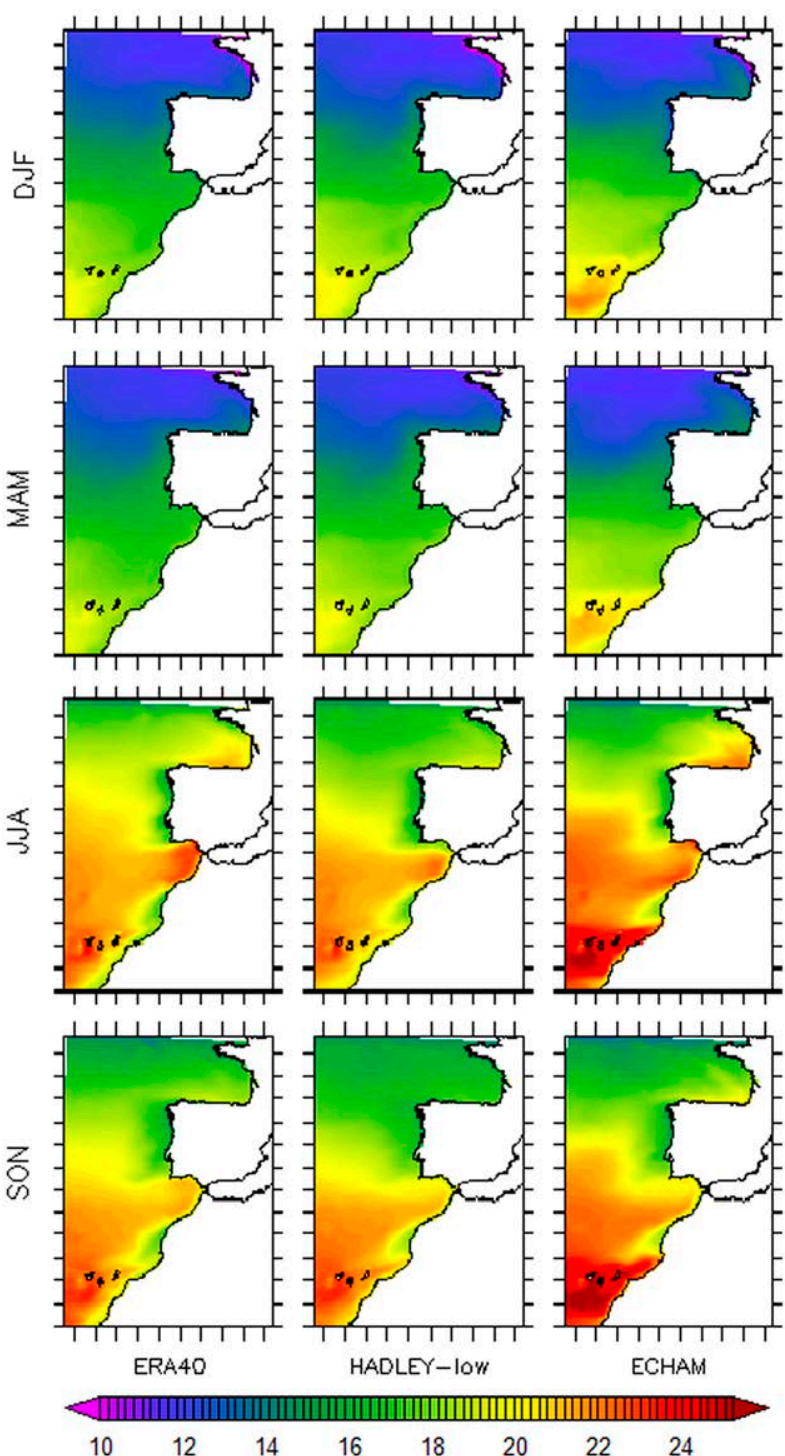

Fig. 2. - SST seasonal means of the hindcast forced with ERA40 and of the control simulations forced with HADLEY-low and ECHAM for the common period 1961-2000. The seasons are denoted by DJF (winter), MAM (spring), JJA (summer) and SON (autumn). Units are ${ }^{\circ} \mathrm{C}$.

Figure 2 shows the SST seasonal means of the hindcast forced with ERA40 and of the control simulations forced with HADLEY-low and ECHAM for the common period 1961-2000. The spatial patterns of the seasonal averages are quite similar: overall they are characterized by a latitudinal gradient pointing to the south, and by the presence of upwelled, cold waters along the Iberian and Moroccan coasts in summer and autumn. In terms of magnitude, the HADLEY-low control simulation is quite similar to the hindcast forced with ERA40 (maximum bias of $+0.52^{\circ} \mathrm{C}$ in summer, of the order of $\pm 0.2^{\circ} \mathrm{C}$ for the other seasons), while the control simulation forced with ECHAM overestimates the hindcast temperatures, particularly in winter $\left(+0.55^{\circ} \mathrm{C}\right)$ and autumn $\left(+0.54^{\circ} \mathrm{C}\right)$. No drift or other major fault was detected in the control simulations, which were therefore considered satisfactory enough as to be the starting point for future projections.

\section{Future projections and the climate of the 21st century}

An initial approach to the changes that may occur during the 21st century is given by the comparison of the seasonal cycle averaged over the period 2021-2050 (derived from the projections forced with HADLEYlow and ECHAM under the A1B scenario) and the seasonal cycle averaged over the period 1971-2000 (derived from the respective control simulations). All cycles exhibit the same phase, with a peak in August and a minimum in March (Fig. S3); moreover, the differences between the projection and the control seasonal cycles remain constant throughout the year (of the order of $0.5^{\circ} \mathrm{C}$ for HADLEY-low and $0.4^{\circ} \mathrm{C}$ for ECHAM), which means that the amplitude of the seasonal cycle of the scenarios would be similar to that of the control simulations.

Regarding trends, both HADLEY-low and ECHAM show a clear predominance of rising temperatures, but they also show negative trends along the Atlantic Iberian coasts (Fig. 3). The latter are more apparent in summer and autumn and are more intense for HADLEY-low, while in the ECHAM projection the negative trends are weaker and confined to the SW of Iberia. The location and seasonality of the negative trends point towards an enhancement of the seasonal upwelling; this issue will be examined in the discussion section, altogether with the changes obtained for SSS.

When the 2001-2050 trends are averaged over the whole domain, they are statistically significant for each season, as well as for the whole year. The trends are larger in winter $\left(0.23^{\circ} \mathrm{C} /\right.$ decade for HADLEY-low and $0.25^{\circ} \mathrm{C} /$ decade for ECHAM) and more moderate in summer $\left(0.15^{\circ} \mathrm{C} /\right.$ decade and $0.18^{\circ} \mathrm{C} /$ decade for HADLEY - low and ECHAM, respectively). The overall values are $0.17^{\circ} \mathrm{C} /$ decade for HADLEY-low and $0.21^{\circ} \mathrm{C} /$ decade for ECHAM. However, these spatial mean values are not representative, as they mix two very distinct patterns: the clearly positive trends (between $0.2^{\circ} \mathrm{C}$ and $0.3^{\circ} \mathrm{C} /$ decade) obtained in the open sea in the two model projections, and the negative coastal trends, which in HADLEY-low are as large as $-0.2^{\circ} \mathrm{C} /$ decade along the Iberian margin $\left(-0.1^{\circ} \mathrm{C} /\right.$ decade in ECHAM, see Fig. 3$)$.

The regional averaged values are shown in Table 3. In the Cantabrian Sea and the Atlantic Iberian margin the ECHAM trends are $+0.23^{\circ} \mathrm{C}$ and $+0.13^{\circ} \mathrm{C} /$ decade, respectively, while they are not statistically significant for HADLEY-low. Note that the Atlantic margin region does not show negative trends because its domain covers not only the upwelling system but also an open-sea region. In the Gulf of Cádiz and in the Canary Islands the trends are $+0.17^{\circ} \mathrm{C}$ and $+0.17^{\circ} \mathrm{C} /$ decade for ECHAM, and $+0.13^{\circ} \mathrm{C}$ and $+0.22^{\circ} \mathrm{C} /$ decade for HADLEY-low .

\section{SEA SURFACE SALINITY}

\section{Validation of the hindcasts and comparison with the control simulations}

The SSS fields of the hindcasts were also compared with the monthly Ishii database (Ishii and Kimoto 

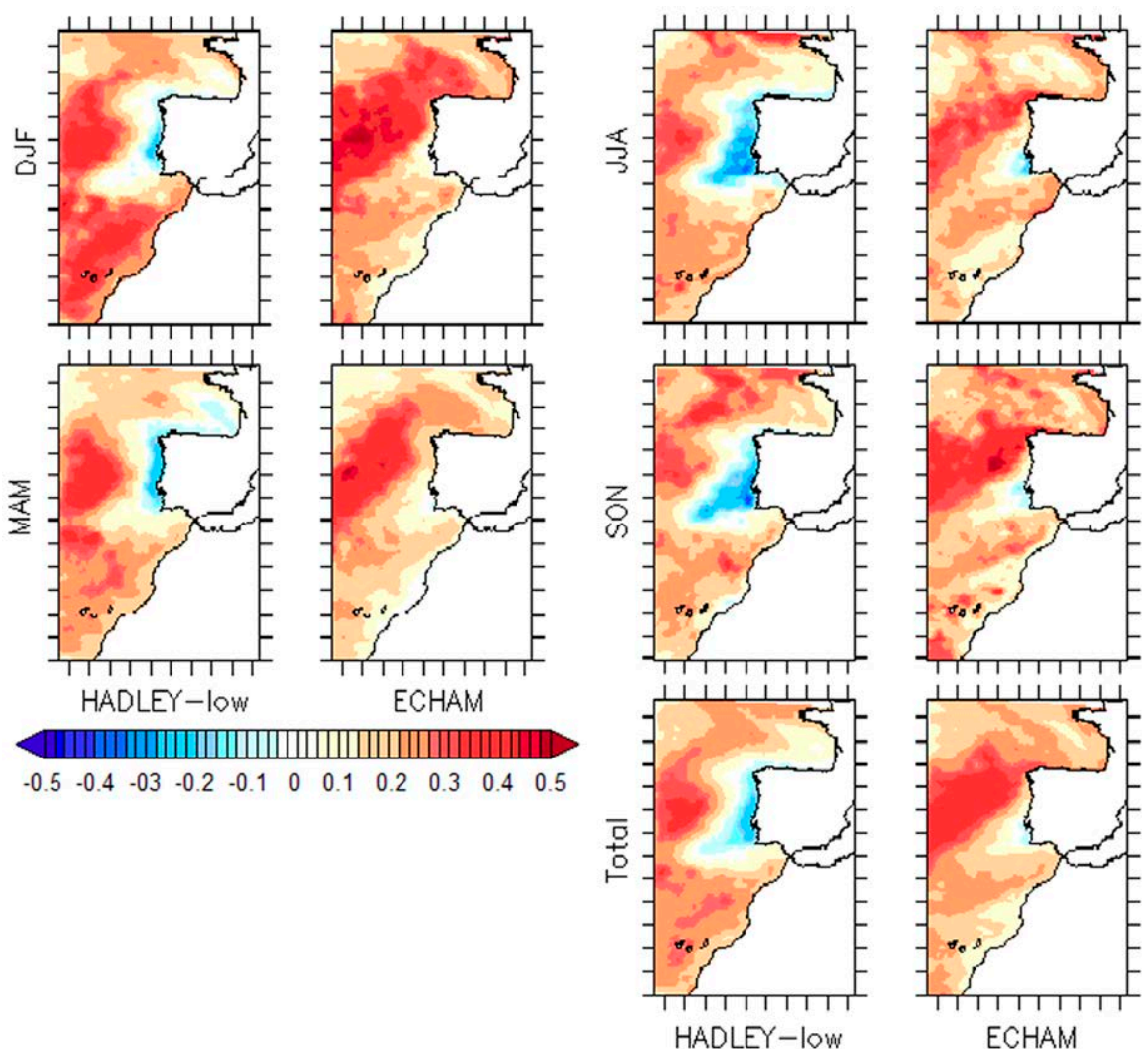

Fig. 3. - Seasonal and total SST trends computed from the HADLEY-low and ECHAM projections (2001-2050). The seasons are denoted by DJF (winter), MAM (spring), JJA (summer) and SON (autumn). Trends are statistically significant (at the $95 \%$ confidence level) all over the domain. Units are ${ }^{\circ} \mathrm{C} /$ decade.

Table 3.-Differences between the SST mean value, standard deviation and 95th percentile averaged for the period 2021-2050 (obtained from the HADLEY-low/ECHAM projections) and those averaged for the period 1971-2000 (obtained from the respective HADLEY-low/ECHAM control simulations). Trends computed for the period 2011-2050 are also given; those marked with (*) are not statistically significant at the $95 \%$ confidence level.

\begin{tabular}{|c|c|c|c|c|c|}
\hline Scenario - control & $\begin{array}{l}\text { SST } \\
\text { HADLEY-low / ECHAM }\end{array}$ & $\begin{array}{l}\text { Difference in mean } \\
\text { value }\left({ }^{\circ} \mathrm{C}\right)\end{array}$ & $\begin{array}{l}\text { Difference in Std } \\
\left({ }^{\circ} \mathrm{C}\right)\end{array}$ & $\begin{array}{l}\text { Difference in } 95^{\text {th }} \\
\text { percentile }\left({ }^{\circ} \mathrm{C}\right)\end{array}$ & $\begin{array}{l}\text { 2001-2050 Trend } \\
\left({ }^{\circ} \mathrm{C} / \text { decade }\right)\end{array}$ \\
\hline Cantabrian Sea & & $+0.42 /+0.91$ & $+0.31 /-0.01$ & $+0.92 /+0.94$ & $+0.03(*) /+0.13$ \\
\hline Atlantic margin & & $+0.13 /+0.51$ & $-0.08 /+0.01$ & $+0.26 /+0.53$ & $-0.07(*) /+0.23$ \\
\hline Gulf of Cádiz & & $+0.80 /+0.31$ & $+0.10 /+0.17$ & $+1.45 /+0.79$ & $+0.13 /+0.17$ \\
\hline Canary Islands & & $+1.04 /+0.30$ & $+0.02 /+0.13$ & $+1.06 /+0.59$ & $+0.22 /+0.17$ \\
\hline
\end{tabular}

2009). Regarding the mean values, both the hindcast forced with ERA-Interim and the one forced with ERA40 slightly overestimate the salinity of Ishii in the Canary Islands region (see Fig. S1 for ERA40). However, the most important differences are found along the French coast of the Bay of Biscay and, to a lesser extent, along the Cantabrian Spanish coasts, where the hindcast SSS is lower than the Ishii SSS. These discrepancies are likely related to the plumes of the Loire and Garonne rivers; again, the low resolution of the Ishii product probably prevents a correct representation of the sharp salinity gradients associated with these two major river outflows. The higher standard deviation of the hindcasts in these coastal regions also points to the Ishii database rather than to the hindcasts as the one having problems in resolving the short-scale spatial structures. Unlike for SST, the hindcasts cannot be validated against SSS time series, since the buoys do not record salinity. The regional averaging of SSS parameters is given in Table 4 . The trends inferred for the last decades of the 20th century are all negative, but they are only statistically significant in the Gulf of Cádiz $(-0.2 \mathrm{psu} /$ decade for the ERA40 hindcast period 1961-2000).

Figure 4 shows the SSS seasonal means obtained from the hindcast forced with ERA40 and those obtained from the control simulations forced with HADLEY-low and ECHAM for the common period 1961-2000. All seasons are characterized by a clear latitudinal gradient that migrates seasonally. Another important feature is the low salinity associated with the discharge of large rivers like the Loire and Garonne on the French coast, which also exhibit a clear seasonal behaviour. These features are similarly represented in the hindcasts and in the control simulations, though the latter slightly underestimate the SSS of the hindcast forced with ERA40. The largest seasonal differences occur in autumn, when the negative mean bias with respect to ERA40 reaches -0.20 psu for the control simulation of ECHAM and -0.19 psu for HADLEY- 


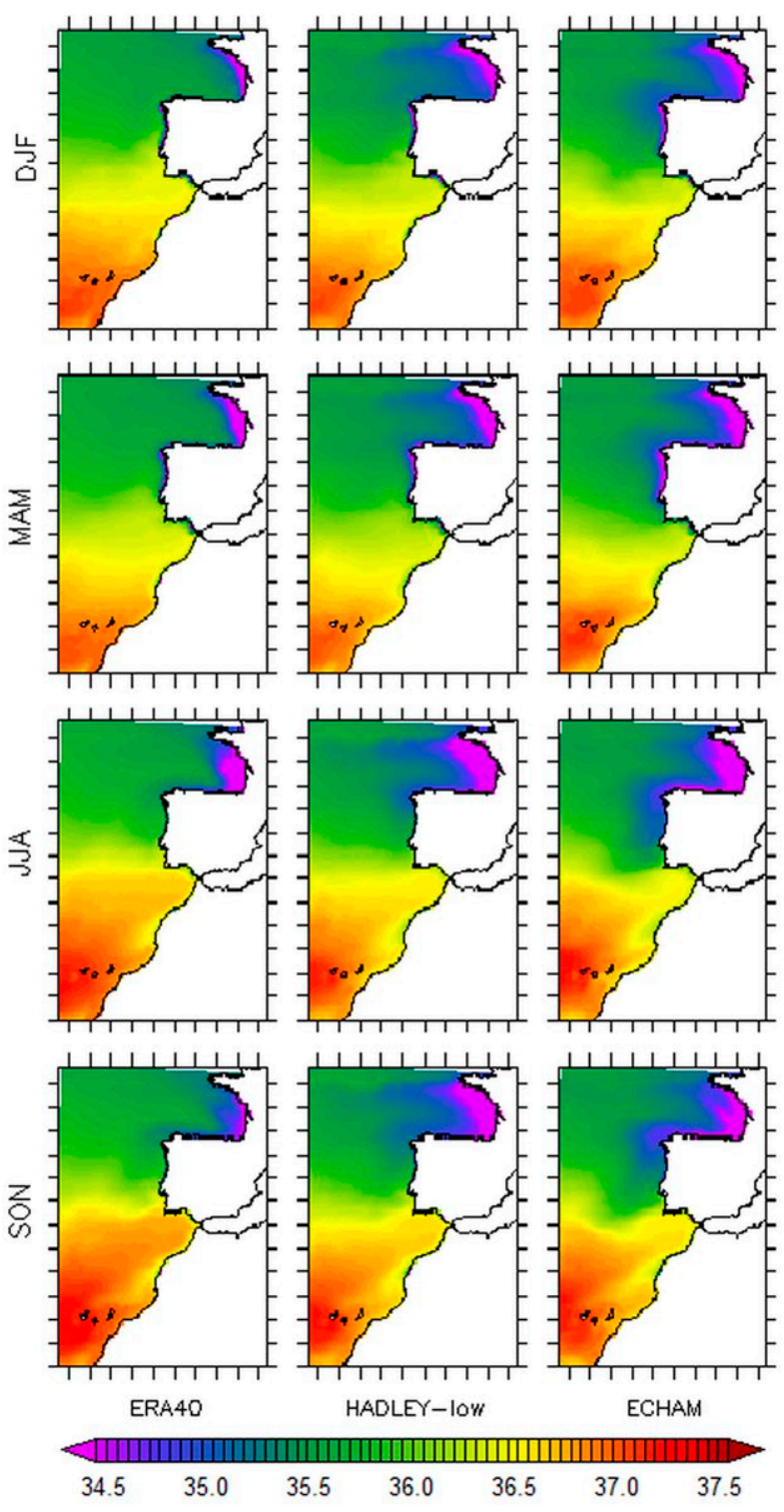

Fig. 4. - SSS seasonal means of the hindcast forced with ERA40 and of the control simulations forced with HADLEY-low and ECHAM for the common period 1961-2000. The seasons are denoted by DJF (winter), MAM (spring), JJA (summer) and SON (autumn). Units are psu.

low. The largest differences are found off the Galician and Portuguese coasts and in the Gulf of Cádiz.

\section{Future projections and the climate of the 21st century}

While the control simulations of ECHAM and HADLEY-low are very similar, there are large discrepancies in their respective projections (Fig. 5).
Both models show an overall decrease in the SSS of the region during the first 50 years of this century, but with important differences in magnitude and spatial distribution. In particular, HADLEY-low shows very marked negative trends $(-0.2 \mathrm{psu} / \mathrm{decade})$ on the Cantabrian and Atlantic coasts of the Iberian Peninsula, but unlike those obtained for SST they extend well offshore. The same model shows increasing SSS trends in the southern half of the domain (of the order of +0.05 psu/decade), particularly near the Canary Islands. Conversely, ECHAM shows a more homogenous spatial picture, with small to moderate negative trends that are more pronounced off the southern coasts of Portugal (up to $-0.1 \mathrm{psu} / \mathrm{decade}$ ) and around the Canary Islands. This is obviously not what would be expected from an enhancement of the coastal upwelling system (which should result in positive SSS trends), pointing therefore to the confluence of additional, distinct processes. Again, these processes will be examined in the discussion section, in the light of additional information.

The regional characterization of the trends (and other parameters) illustrates the differences between the two models (see Table 5). HADLEY-low shows regions with positive and negative trends, but the only ones that are statistically significant are the negative trends of the Atlantic margin. On the other hand, ECHAM shows negative trends between -0.03 and $-0.05 \mathrm{psu} /$ decade everywhere except in the Cantabrian Sea, where they are virtually null, but the only ones that are statistically significant are those of the Gulf of Cádiz.

\section{SEA LEVEL}

\section{Validation of the hindcasts and comparison with the control simulations}

Sea level is a particular variable in the sense that it is obtained by adding different contributions (see e.g. Griffies and Greatbatck 2012, or Jordà and Gomis 2013, for an updated review). The constituents of longterm sea level variability are the thermal expansion/ contraction derived from changes in the hydrography (the so called steric or baroclinic component); the barotropic component forced by atmospheric pressure and wind; and the mass component, due essentially to ice melting, but also to mass redistributions not linked to the meteorological forcing. Regarding the baroclinic component, it must be noted that for models using the Boussinesq approximation (most of them) it does not coincide with the sea surface height ( $\mathrm{SSH}$ ) of the model. The reason is that Boussinesq models conserve volume, and therefore SSH can only account for sea

Table 4. - Mean value, standard deviation, 95th percentile and trend of SSS obtained from the hindcast forced with ERA40 (1961-2000) and averaged over the regions of Figure 1B. The SSS values are those given by the hindcast forced with ERA40 (1961-2000). Trends marked with (*) are not statistically significant at the $95 \%$ confidence level.

\begin{tabular}{|c|c|c|c|c|}
\hline $\begin{array}{c}\text { SSS } \\
\text { ERA-40 hindcast }\end{array}$ & $\begin{array}{l}\text { Mean value } \\
\text { (psu) }\end{array}$ & $\begin{array}{l}\text { Std } \\
(\mathrm{psu})\end{array}$ & $95^{\text {th }}$ percentile $(\mathrm{psu})$ & $\begin{array}{l}\text { 1961-2000 Trend } \\
\text { (psu/decade) }\end{array}$ \\
\hline Cantabrian Sea & 35.18 & 0.37 & 35.78 & $-0.08(*)$ \\
\hline Atlantic margin & 35.90 & 0.26 & 36.36 & $-0.05(*)$ \\
\hline Gulf of Cádiz & 36.46 & 0.19 & 36.82 & -0.02 \\
\hline Canary Islands & 36.92 & 0.13 & 37.17 & $+0.01(*)$ \\
\hline
\end{tabular}



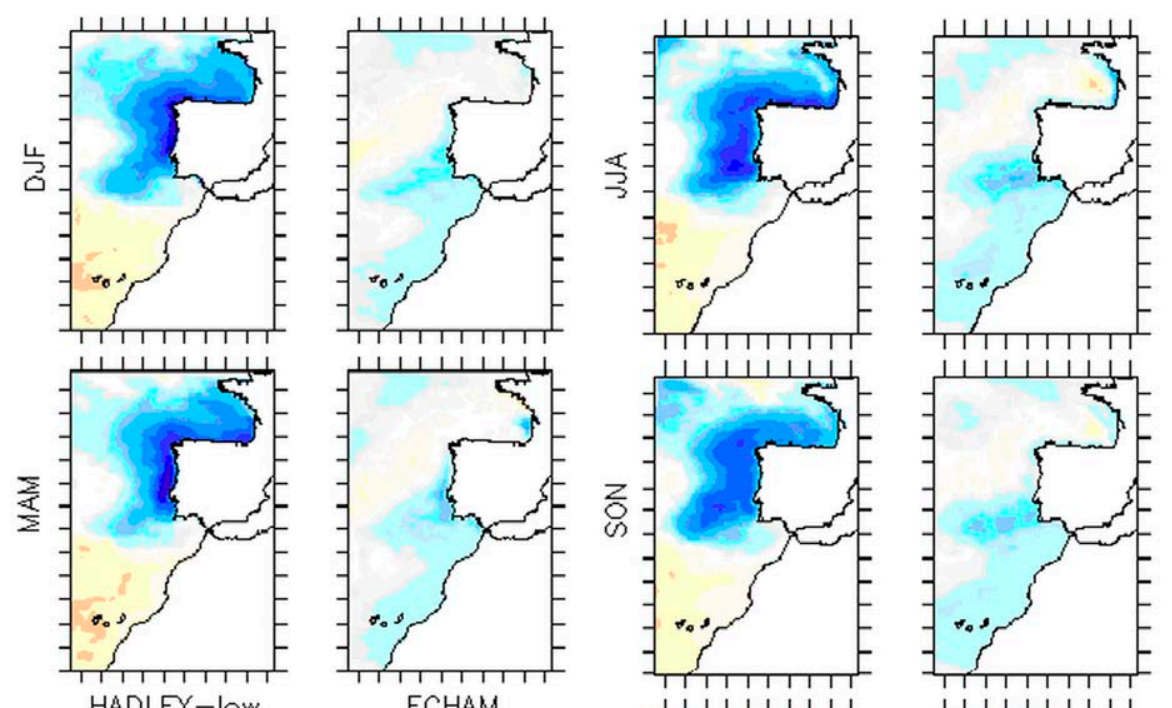

HADLEY-IOW

ECHAM
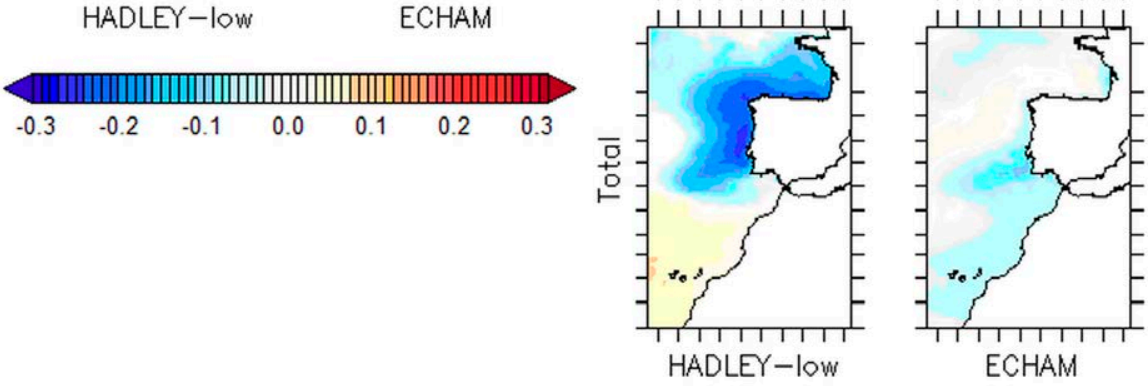

ECHAM

Fig. 5. - Seasonal and total SSS trends computed from the HADLEY-low and ECHAM projections (2001-2050). The seasons are denoted by DJF (winter), MAM (spring), JJA (summer) and SON (autumn). The areas where trends are not statistically significant at the $95 \%$ confidence level have been blanked. Units are psu/decade.

Table 5. - Differences between the SSS mean value, standard deviation and 95th percentile averaged for the period 2021-2050 (obtained from the HADLEY-low/ECHAM projections) and those averaged for the period 1971-2000 (obtained from the respective HADLEY-low/ECHAM control simulations). Trends computed for the period 2011-2050 are also given; those marked with (*) are not statistically significant at the $95 \%$ confidence level.

\begin{tabular}{|c|c|c|c|c|c|}
\hline Scenario-control & $\begin{array}{l}\text { SSS } \\
\text { HADLEY-low / ECHAM }\end{array}$ & $\begin{array}{l}\text { Difference in mean } \\
\text { value (psu) }\end{array}$ & $\begin{array}{l}\text { Difference in Std } \\
(\mathrm{psu})\end{array}$ & $\begin{array}{l}\text { Difference in } 95^{\text {th }} \\
\text { percentile (psu) }\end{array}$ & $\begin{array}{l}\text { 2001-2050 trend } \\
\text { (psu/decade) }\end{array}$ \\
\hline Cantabrian Sea & & $-0.95 /+0.01$ & $+0.06 /+0.00$ & $-0.84 /+0.06$ & $-0.09\left(^{*}\right) /+0.00(*)$ \\
\hline Atlantic margin & & $-0.68 /-0.08$ & $+0.20 /+0.02$ & $-0.25 /-0.03$ & $-0.21 /-0.03(*)$ \\
\hline Gulf of Cádiz & & $-0.04 /-0.23$ & $+0.10 /+0.02$ & $+0.13 /-0.20$ & $+0.00(*) /-0.05$ \\
\hline Canary Islands & & $+0.16 /-0.26$ & $+0.10 /+0.03$ & $+0.35 /-0.19$ & $+0.06\left(^{*}\right) /-0.04(*)$ \\
\hline
\end{tabular}

level spatial gradients, not for overall expansions/contractions. The latter must be obtained by integrating the thermosteric component over the whole model domain at each time step, which results in a time-dependent, spatially-constant term that must be added to SSH (for more details see Jordà and Gomis 2013).

The baroclinic and mass components of sea level cannot be directly validated, since there are no longterm observations of such components. The barotropic component can be validated at intra-seasonal scales, at which this is by far the dominant contribution to observed sea level. Although barotropic sea level is just one of the components of total sea level, its validation is important, because it is the most important contributor to total sea level extremes.

The barotropic sea level was validated by comparing the barotropic model outputs with tide gauge records from which we removed the seasonal cycle (which is mostly baroclinic). Since we cannot remove the mass component, we cannot expect a complete agreement between barotropic sea level and de-seasoned tide gauge records. However, the ice melting contribution (the largest contribution of the mass component) is a low-frequency signal with a small impact at intra-seasonal scales. The barotropic component was validated with daily values and by computing RMS differences, correlation and percentage of variance reduction for the available tide gauges (shown in Table 6). The RMS errors are of the order of $5 \mathrm{~cm}$ and the correlation is high

Table 6. - Validation of the hindcast of barotropic sea level forced with ERA40 against tide gauge records spanning the whole hindcast period (1961-2000). Tide gauge values and the closest hindcast grid point were compared in terms of RMS error, correlation and the reduction of tide gauge variance when subtracting the hindcast values. All parameters were computed from daily values.

Barotropic sea level:

ERA-40 hindcast vs. RMSE $(\mathrm{cm})$ Correlation Variance

TG records

\begin{tabular}{llll}
\hline Bilbao & 4.33 & 0.91 & 82.93 \\
Santander & 5.90 & 0.86 & 72.79 \\
Gijón & 5.64 & 0.89 & 78.39 \\
A Coruña & 5.80 & 0.88 & 77.21 \\
Cascais & 5.78 & 0.76 & 57.77 \\
\hline
\end{tabular}



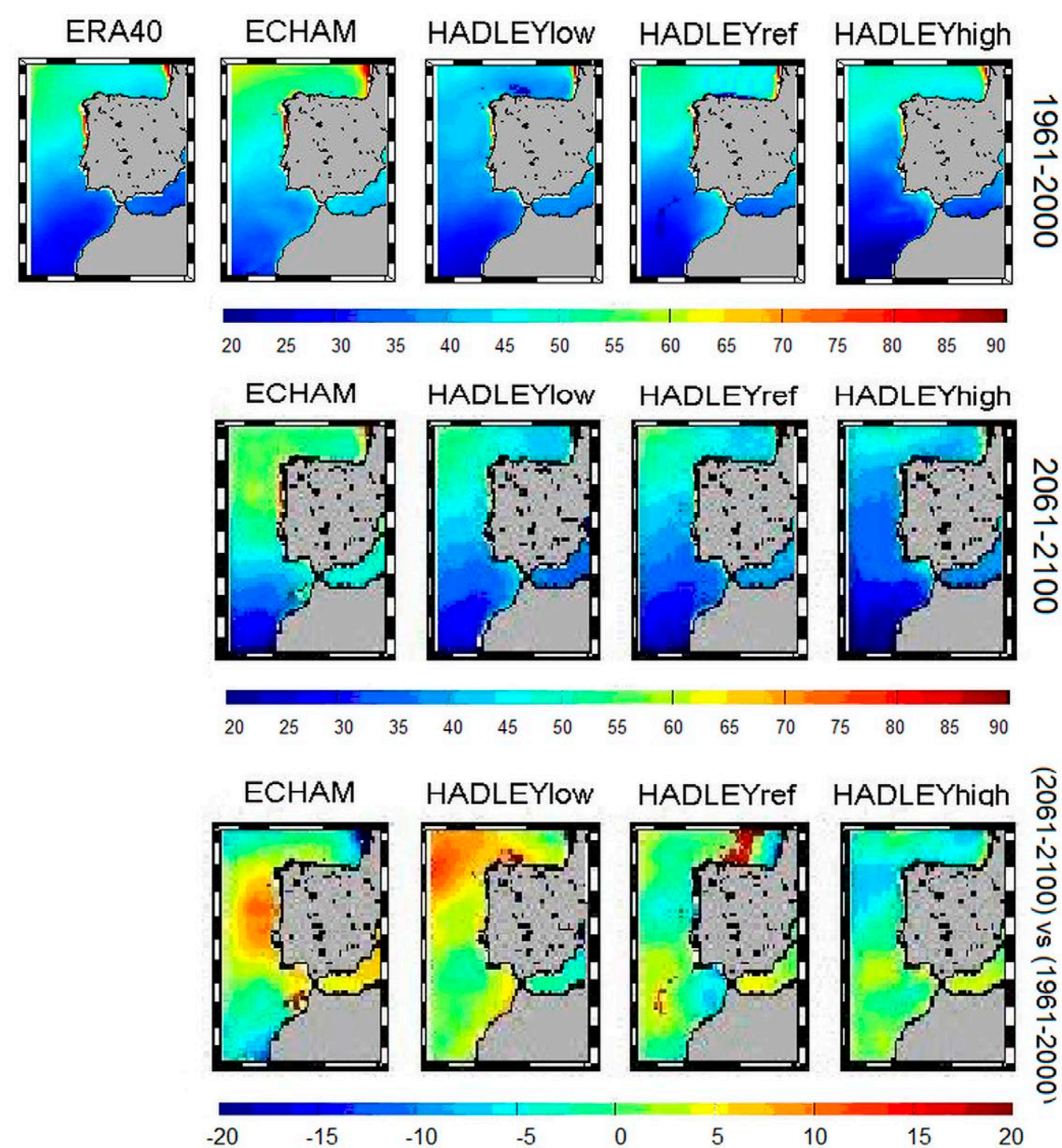

Fig. 6. - (Upper panels) 50-year return levels of barotropic sea level computed from the hindcast forced with ERA-40 and from the control simulations forced with ECHAM, HADLEY-low, HADLEY-ref and HADLEY-high for the common period 1961-2000. (Middle panels) 50 -year return levels of barotropic sea level computed from the projections forced with ECHAM, HADLEY-low, HADLEY-ref and HADLEYhigh for the period 2061-2100. (Lower panels) Difference between the corresponding upper and middle panels. Note that mean sea level rise is not included in this estimate. Units are cm.

for all the records. The maximum explained variance is obtained at Bilbao, where the hindcast explains more than $80 \%$ of the observed variability; the lowest value $(55 \%)$ is obtained at Cascais. Overall, these values suggest that the barotropic output is a good approach to the actual atmospheric component of sea level.

Regarding the comparison between the control simulations and the hindcasts, the baroclinic component shows that both HADLEY-low and ECHAM reproduce the main characteristics of the hindcast (Fig. S4). These are a latitudinal gradient (with higher sea levels to the south) and a clear seasonal cycle (higher sea levels in summer/autumn). Conversely, the values produced by ECHAM around the Iberian Peninsula in summer and autumn are too high. Also the barotropic component of the hindcast is well reproduced by the control simulations of the different models for all seasons (Fig. S5). Although there are some differences between the models, these are small compared with the spatial and seasonal variability. Considering that at least the patterns of both the baroclinic and barotropic hindcasts are well reproduced by the respective control simulations, this will also be the case for total sea level, since the missing mass component is virtually homogeneous in space (Lorbacher et al. 2012).

The barotropic hindcasts were also compared with the control simulations in terms of extreme levels. Figure 6 (upper panels) shows the 50-year return levels; the patterns of the hindcast and of the control simulations are similar except perhaps for HADLEY-low, with higher return levels in the Bay of Biscay $(\sim 50 \mathrm{~cm})$ due to the marked storminess of the region and lower values $(\sim 20 \mathrm{~cm})$ at lower latitudes. 


\section{Future projections and the climate of the 21st century}

The 2000-2050 total sea level trends, evaluated for each season and for the whole year, are presented in Figure 7. It should be noted that the figure includes the baroclinic and barotropic components, but not the mass component derived from the ice melting. Since the missing mass component is expected to be fairly homogeneous in space, what this Figure reflects is the spatial pattern of sea level rise in the region. On the other hand, the results of averaging the trends over the whole domain are presented in Table 7. For both models the trends are positive and significant, but there are important differences between them. ECHAM shows more homogeneous trends (a mean value of $1.36 \pm 0.27 \mathrm{~cm} /$ decade) and they are slightly larger in summer, while HADLEY-low shows marked differences between regions (mean value of $2.18 \pm 0.54 \mathrm{~cm} /$ decade) and the largest trends are projected for winter. The differences are clearly due to the baroclinic component, since for the barotropic component the differences between models are of the order of $0.1 \mathrm{~cm} /$ decade (not shown).

A feature worth noting is that the uncertainty associated with the decadal variability and the differences between models are smaller than the uncertainty of the ice melting component. This component was estimated to contribute an additional $1.2 \mathrm{~cm} /$ decade according to the IPCC AR4 (see for instance Meehl et al. 2007),
Table 7. - Seasonal and total sea level trends (including the baroclinic and barotropic components, but without the contribution of ice melting and mass redistribution in the NE Atlantic) averaged over the whole domain and computed from the projections forced with HADLEY-low and ECHAM (200-2050). The standard deviation of the trends within the domain is also quoted. Units are cm/ decade.

\begin{tabular}{lcc}
\hline & ECHAM & HADLEY-low \\
\hline Winter & $1.62 \pm 0.34$ & $2.71 \pm 0.60$ \\
Spring & $1.60 \pm 0.42$ & $1.96 \pm 0.48$ \\
Summer & $1.60 \pm 0.32$ & $2.10 \pm 0.59$ \\
Autumn & $1.41 \pm 0.35$ & $2.23 \pm 0.62$ \\
Total & $1.36 \pm 0.27$ & $2.18 \pm 0.54$ \\
\hline
\end{tabular}

while more recent estimates elevate that rate to $4.6 \mathrm{~cm} /$ decade (see e.g. Bamber and Aspinall 2013). That is, the sea level trends presented here probably reflect the spatial variability of the trends, but their magnitude will strongly depend on the missing ice melting component.

For the projection of extreme sea levels we used the barotropic component, the one that best reflects the storminess activity. The middle panels of Figure 6 show the 50-year return levels calculated for the period 2061-2100, while the lower panels show the differences between the latter and those computed from the respective control simulations (1961-2000, shown in the upper panels). The differences are slightly positive $(\sim 10 \mathrm{~cm})$ for ECHAM and HADLEY-low and slightly negative $(\sim-10 \mathrm{~cm})$ for HADLEY-ref and HADLEYhigh. These results suggest the absence of clear trends in the storminess of the region. That is, extreme sea
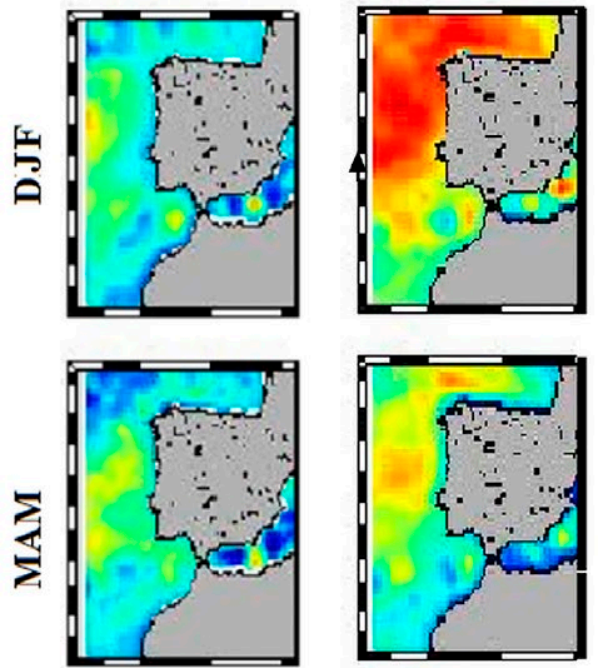

ECHAM

HADLEY-low
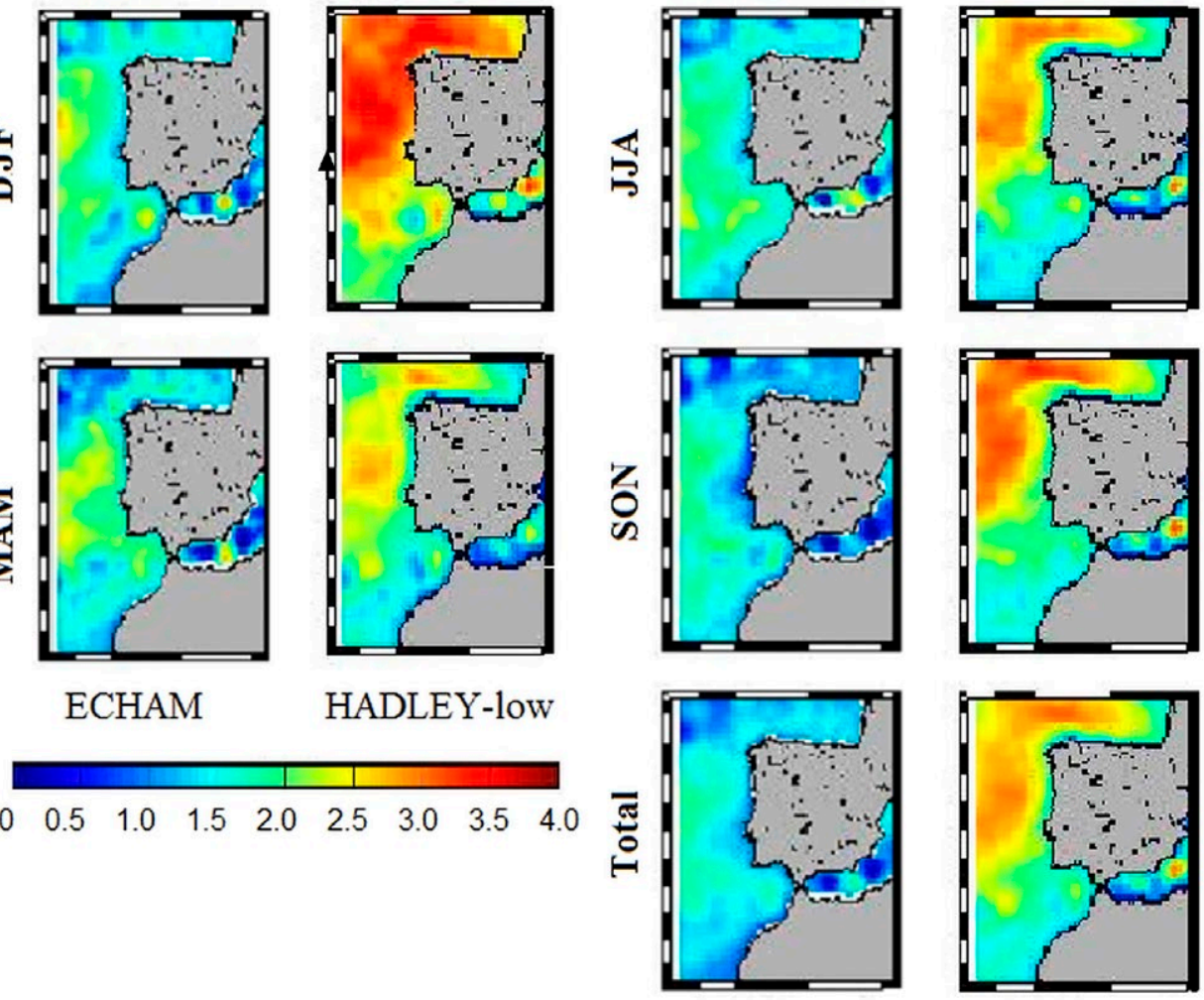

ECHAM

Fig. 7. - Seasonal and total sea level trends (including the baroclinic and barotropic components, but without the contribution of ice melting and mass redistribution in the NE Atlantic) computed from the ECHAM and HADLEY-low projections (2001-2050). The seasons are denoted by DJF (winter), MAM (spring), JJA (summer) and SON (autumn). Trends are statistically significant at the 95\% confidence level everywhere. Units are $\mathrm{cm} /$ decade. 
Table 8. - Validation of significant wave heights from the hindcast forced with ERA40 (1961-2000) against buoy observations. Buoy values and the closest hindcast grid point were compared for the common period (quoted for each buoy) in terms of the bias, root-mean-square error (RMSE), correlation and the reduction of buoy variance when subtracting the hindcast. All parameters were computed from daily values.

\begin{tabular}{lccrr}
\hline Buoy & $\begin{array}{c}\text { Comparison } \\
\text { period (days) }\end{array}$ & $\begin{array}{c}\text { Bias: <Hs_hind }> \\
-<\text { Hs_buoy }>(\mathrm{m})\end{array}$ & $\begin{array}{c}\text { RMSE } \\
(\mathrm{m})\end{array}$ & $\begin{array}{c}\text { Variance reduction } \\
(\%)\end{array}$ \\
\hline Gulf of Cádiz & 1826 & -0.05 & 0.33 & 83.94 \\
Gran Canaria & 1648 & -0.55 & 0.63 & 0.90 \\
Tenerife Sur & 1226 & 0.03 & 0.29 & 0.87 \\
Bilbao & 2718 & -0.49 & 0.69 & 0.76 \\
Cabo Penhas & 1279 & -0.35 & 0.56 & 0.93 \\
Cabo Silleiro & 996 & -0.43 & 0.63 & 0.92 \\
Estaca Bares & 1486 & -0.51 & 0.72 & 0.93 \\
Villano Sisargas & 803 & -0.52 & 0.71 & 86.93 \\
\hline
\end{tabular}

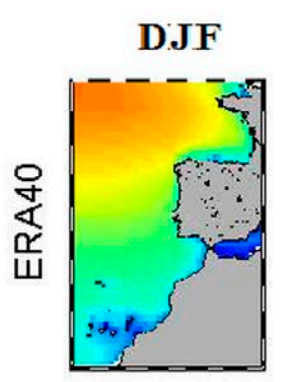

\section{MAM}
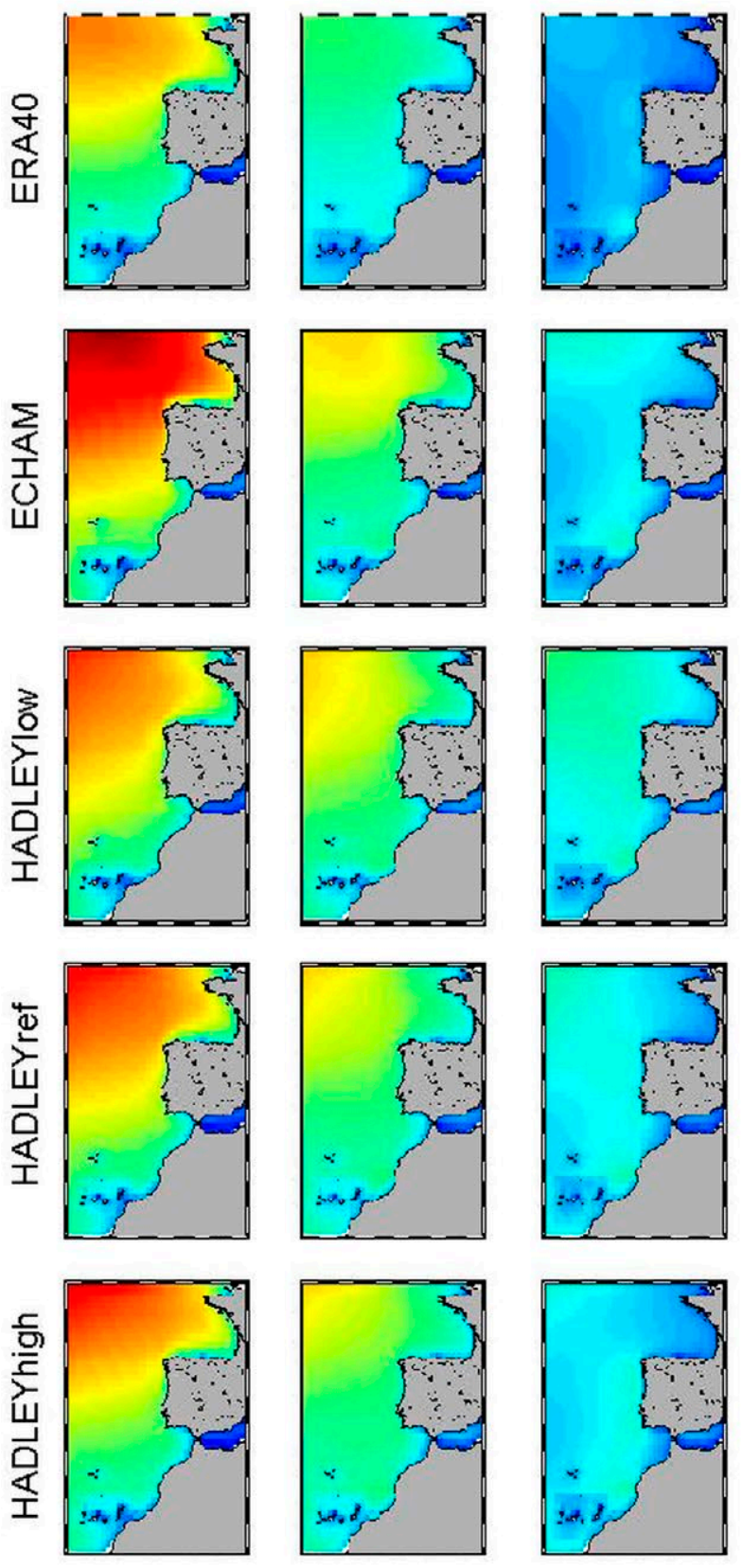

SON
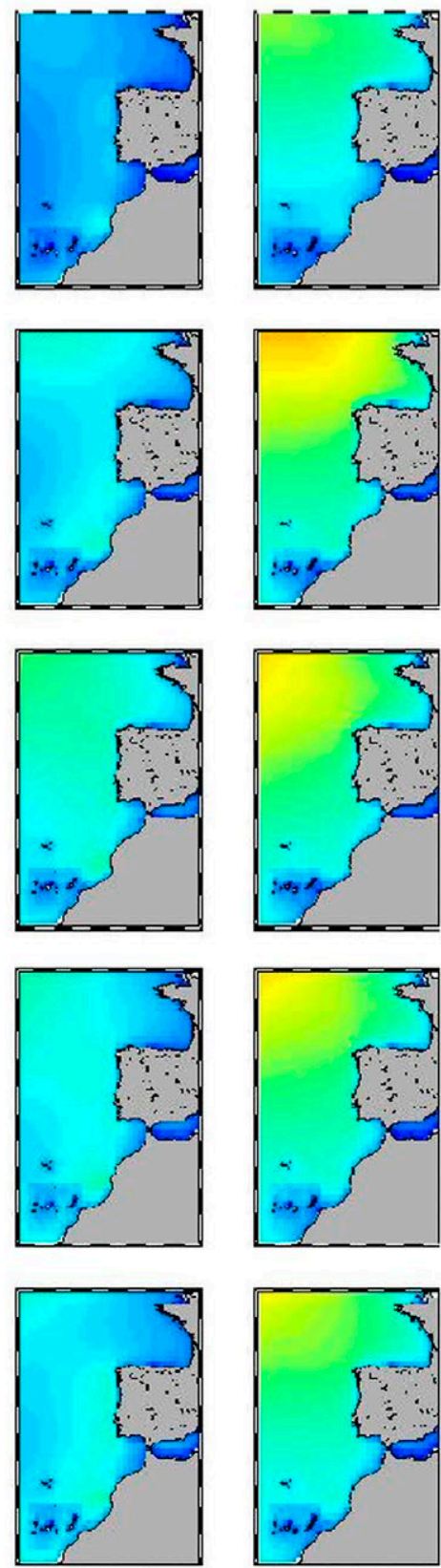

$0 \quad 0.5 \quad 1.0$

1.5

2.0

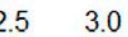

3.5

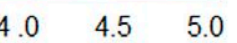

Fig. 8. - SWH seasonal means of the hindcast forced with ERA40 and of the control simulations forced with ECHAM, HADLEY-low, HADLEY-ref and HADLEY-high for the common period 1961-2000. The seasons are denoted by DJF (winter), MAM (spring), JJA (summer) and SON (autumn). Units are m. 

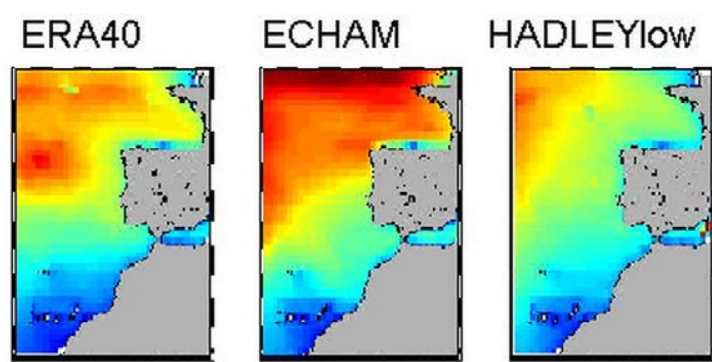

\section{HADLEYref}

HADLEYhigh
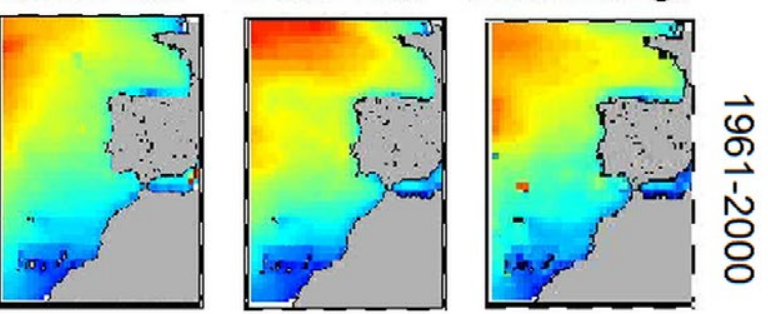

$$
2
$$

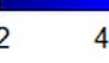

$6 \quad 8 \quad 10$

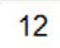

14

$16 \quad 18$

20

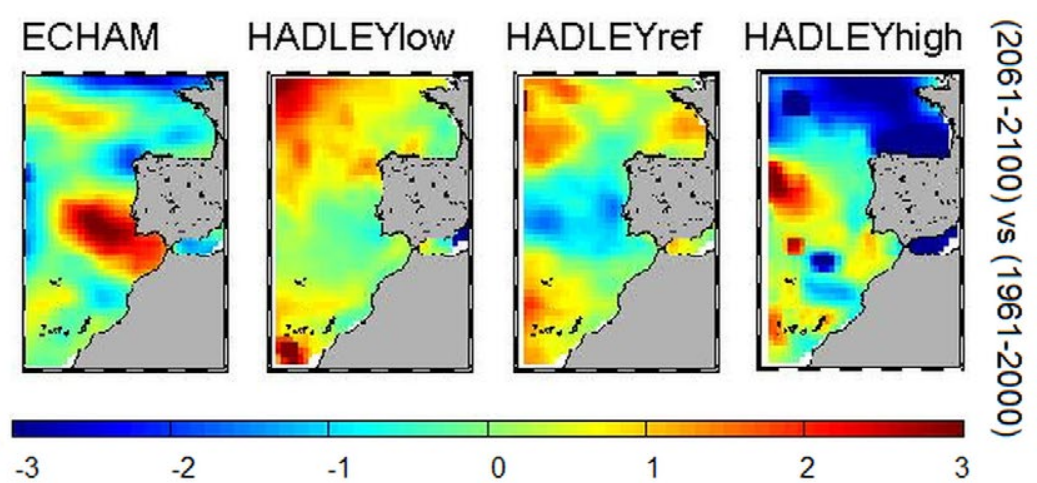

Fig. 9. - (Upper panels) 50-year return levels of SWH computed from the hindcast forced with ERA-40 and from the control simulations forced with ECHAM, HADLEY-low, HADLEY-ref and HADLEY-high for the common period 1961-2000. (Lower panels) Differences between the 50-year return levels of SWH computed from the projections forced with HADLEY-low, HADLEY-ref, HADLEY-high and ECHAM (period 2061-2100) and the corresponding control simulations are shown in the upper panels. Units are $\mathrm{m}$.

levels will be higher in the 21 st century, but because of the increase in mean sea level, not because of an increase in the storminess. Of course, there will also be an increase in the negative extremes (a reduction in absolute terms; they will be 'less negative') for the same reasons.

\section{WAVES}

\section{Validation of the hindcasts and comparison with the control simulations}

The wave hindcasts were compared with daily buoy observations located along the coasts of the domain (see Table 8 for the comparison and Figure 1B for the location of the buoys). In terms of SWH, the bias between the hindcast and the buoys ranges from $3 \mathrm{~cm}$ at Tenerife Sur to $-55 \mathrm{~cm}$ at Gran Canaria, with a mean value of $-36 \mathrm{~cm}$. That is, the hindcast underestimates SWH in practically all buoys. The RMS error ranges from $33 \mathrm{~cm}$ in the Gulf of Cádiz to $72 \mathrm{~cm}$ at Estaca de Bares, with an average value of $57 \mathrm{~cm}$. Some of these values may seem high, but to put them in context they must be compared with the SWH variance of each buoy, computing for instance the percentage of the buoy variance explained by the hindcast (last column of Table 8). The latter are higher than $85 \%$ for all buoys except for Tenerife Sur $(61 \%)$ and Gran Canaria (77\%), indicating that some local winds around the Canary Islands are not fully reproduced by the forcing. The correlation is consistent with the lasts statement: it is larger than 0.9 for all buoys except for Tenerife Sur (0.76) and Gran Canaria (0.87). Apart from these discrepancies, the validation of the hindcast is entirely satisfactory.

Regarding the comparison between the hindcast and the control simulations, the patterns are similar for all seasons, with the maximum values being obtained in the NW sector of the domain (less apparent in summer, see Fig. 8). The mean SWH is of the order of 2 $\mathrm{m}$ in winter (up to $4 \mathrm{~m}$ in the NW sector) and $1.5 \mathrm{~m}$ in summer (up to $3 \mathrm{~m}$ in the NW sector). The control simulations overestimate the hindcast by about $10 \%$ in winter (up to $25 \%$ in the case of ECHAM) and by about $30 \%$ in the other seasons. With the exception of the winter values of ECHAM, the control simulations and the hindcast differ in a fairly constant bias throughout the year (about $30 \mathrm{~cm}$ ). That is, the control simulations are closer to the buoy observations (in terms of mean values) than the hindcast.

Figure 9 (upper panels) also compares the results of the hindcasts and of the control simulations but for extreme values, namely in terms of 50-year return levels. As for the mean values, ECHAM considerably overestimates the control return levels, giving about 20 $\mathrm{m}$ in the NW sector while ERA40 gives about $15 \mathrm{~m}$. The control simulations that best reproduce the pattern and magnitude of the hindcast forced with ERA40 are those produced by HADLEY-ref and HADLEY-high.

\section{Future projections and the climate of the 21st century}

The SWH trends projected for the whole 21st century are shown in Figure 10 and summarized in Table 9 , together with the percentage change in comparison 

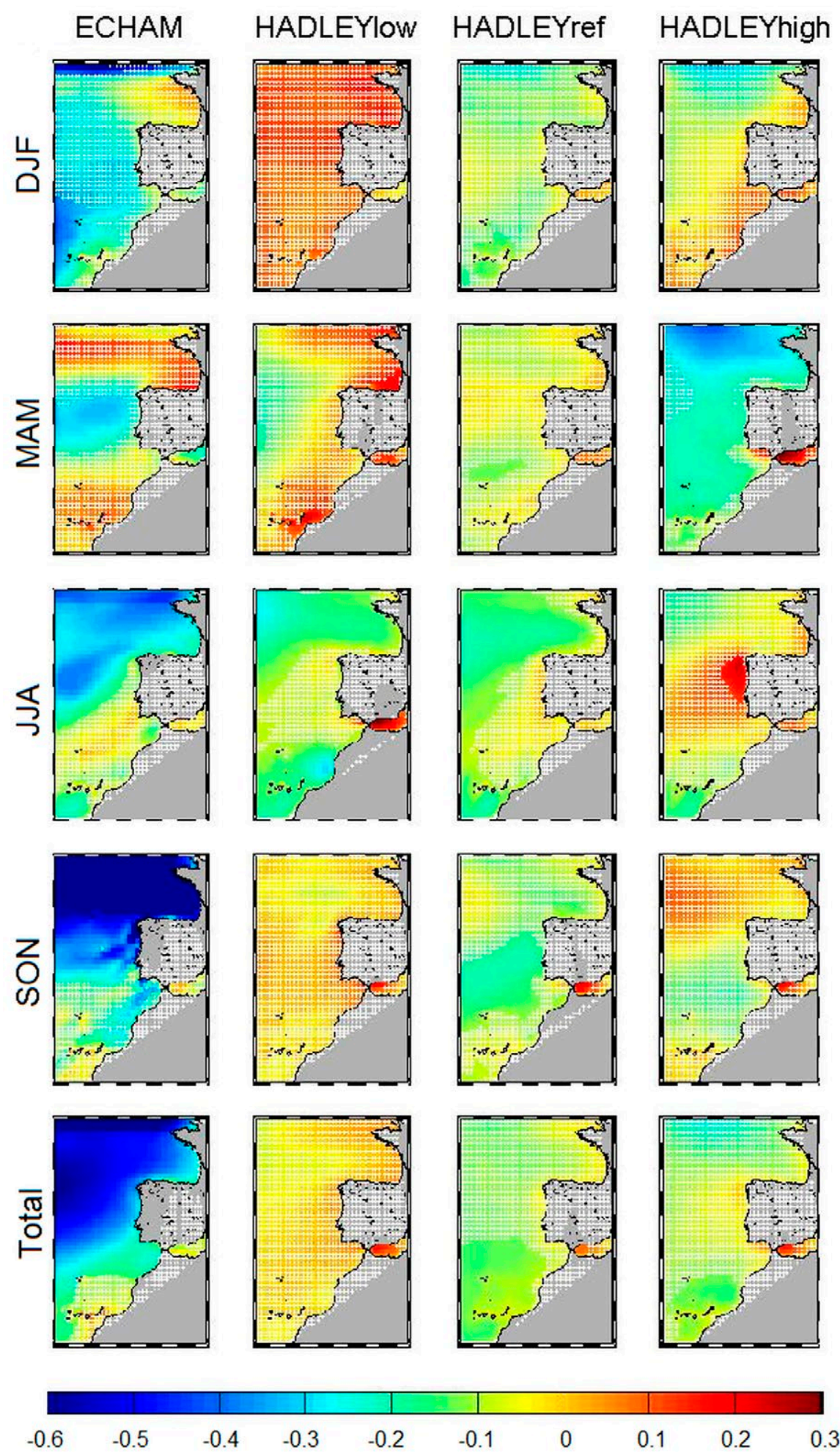

Fig. 10. - Seasonal and total SWH trends computed from the ECHAM, HADLEY-low, HADLEY-ref and HADLEY-high projections (20012100). The seasons are denoted by DJF (winter), MAM (spring), JJA (summer) and SON (autumn). The areas where trends are not statistically significant at the $95 \%$ confidence level have been blurred. Units are $\mathrm{cm} / \mathrm{y}$.

with the past century. Most of the trends are statistically not significant; only ECHAM shows significant negative trends in the NW sector of the domain, where they reach $-5 \mathrm{~cm} /$ decade in autumn. The few areas where trends are statistically significant are not consistent between models, perhaps because the vari- ations are all small (well beneath 10\%) and therefore dependent on the different chronology of the simulations. Most of the projected changes are in fact smaller than the natural variability estimated from the control simulations (ideally the natural variability should be estimated with very long, pre-industrial records or 
Table 9. - Seasonal and total significant wave height (SWH) trends averaged over the whole domain computed from the projections forced with ECHAM, HADLEY-low, HADLEY-ref and HADLEY-high (2000-2100). The standard deviation of the trends within the domain is also quoted. The percentage in brackets is the change of the mean SWH between the periods 2070-2100 and 1970-2000. Units are cm/y.

\begin{tabular}{llrlr}
\hline & \multicolumn{2}{c}{ ECHAM } & HADLEY-low & HADLEY-ref \\
\hline Winter & $-0.18 \pm 0.09(-8 \%)$ & $0.05 \pm 0.05(+2 \%)$ & $-0.07 \pm 0.06(-3 \%)$ \\
Spring & $-0.04 \pm 0.07(-2 \%)$ & $0.06 \pm 0.04(+3 \%)$ & $-0.03 \pm 0.04(-2 \%)$ \\
Summer & $-0.10 \pm 0.04(-7 \%)$ & $-0.06 \pm 0.03(-4 \%)$ & $-0.08 \pm 0.03(-5 \%)$ & $0.01 \pm 0.08(-0.08 \pm 0.06(-4 \%)$ \\
Autumn & $-0.23 \pm 0.08(-13 \%)$ & $0.02 \pm 0.05(+1 \%)$ & $-0.06 \pm 0.04(-4 \%)$ & $-0.03 \pm 0.04(-2 \%)$ \\
Total & $-0.19 \pm 0.07(-10 \%)$ & $0.02 \pm 0.03(+1 \%)$ & $-0.06 \pm 0.04(-3 \%)$ & $-0.03 \pm 0.06(-2 \%)$ \\
\hline
\end{tabular}

simulations, but these are not available). In terms of annual means, ECHAM shows a decrease in SWH of the order of $10 \%$ by the end of the 21 st century, while HADLEY-low shows an increase of $+1 \%$ and HADLEY-ref and HADLEY-high show decreases of $-3 \%$ and $-2 \%$, respectively (Table 9 ). Little can be said about eventual changes in the seasonal cycle, given the disparity between models in the seasonal trends.

The changes in the 50-year return levels of SWH (the differences between the return levels computed for the period 2061-2100 and those computed for 19612000) are shown in Figure 9 (lower panels). There are apparent differences between the two periods, but they are not consistent between models. Thus, HADLEYlow and HADLEY-ref show the largest increases in the return levels (up to a few metres) in the NW and SW sectors of the domain, while they show a slight decrease in the central area. Conversely, HADLEY-high shows a significant decrease in the return levels to the north of the domain, and ECHAM shows the largest changes in the Gulf of Cádiz and adjacent areas. When computing the return levels for other periods $(10,20$ and 100 years, not shown) the results obtained are consistent with those of Figure 9: HADLEY-high always shows an overall decrease in the return levels, while the other models show an increase. However, it must be stated again that computing averages in a domain with such spatial disparity is rather questionable. Overall, the results suggest that the changes in SWH obtained from the projections are small and hardly distinguishable from the natural variability.

\section{DISCUSSION}

The aim of this section is twofold: to place our results in the framework of previous works and to provide further insight into some of the major processes identified in the results.

\section{On the patterns of SST and SSS projections}

As expected, both HADLEY-low and ECHAM show a clear predominance of rising SST in the open sea, as a consequence of the global ocean warming. Both models show trends of $0.2^{\circ} \mathrm{C}$ to $0.3^{\circ} \mathrm{C} /$ decade (that is, an increase of $1^{\circ} \mathrm{C}$ to $1.5^{\circ} \mathrm{C}$ by 2050). These values are in agreement with those obtained by Bopp et al. (2013) from an ensemble of 10 CMIP5 global models. According to these authors, the NE Atlantic SST will increase linearly during the 21 st century, reaching an increase of $2^{\circ} \mathrm{C}$ to $2.5^{\circ} \mathrm{C}$ by 2100 under the RCP8.5 (high-emission) scenario; for the RCP2.6 (low-emission) scenario the increase would be $0.5^{\circ} \mathrm{C}$ to $1^{\circ} \mathrm{C}$ (non-significant in the northern sector of the domain). The SST trends obtained here are closer to RCP8.5 than to RCP2.6, which is in agreement with the fact that the intermediate SRES A1B scenario is closer to RCP8.5 than to RCP2.6 in terms of greenhouse gas concentrations.

Perhaps more interesting is the fact that we obtained negative SST trends along the Atlantic Iberian coasts. It is worth recalling that resolving such regional features is a key advantage of the RCMs used here in comparison with global models, and that this is one of the main motivations of this work. The negative coastal trends are more apparent in the southern sector of the Iberian margin and more marked in summer and autumn. There are differences between the two models (trends are more negative for HADLEY-low than for ECHAM) but they agree in pointing towards a more marked cooling to the SW of Iberia than to the north. Along the African coasts both models show null or slightly positive SST trends, i.e. much weaker than in the open sea.

The location and seasonality of the obtained SST trends points towards an enhancement of the seasonal upwelling. Moreover, they are in agreement with the changes observed during the last few decades; for example, Alves and Miranda (2013) found marked differences between open-sea and coastal trends when running an ORCM forced by ERA-40 and ERAInterim reanalyses and attributed these differences to an intensification of the upwelling system. The differences between the northern and southern sectors of the Iberian margin have also been reported by several authors: Relvas et al. (2009) analysed different SST data sets spanning the last few decades and found an intensification of the upwelling in the southern sector of the Iberian margin, particularly in summer and autumn; and Álvarez et al. (2008) analysed QuikSCAT and PFEL data and attributed the spatial differences in the upwelling system to the interaction between the macroscopic wind regime and coastal orography.

However, the trends obtained for SSS along the Iberian margin are also negative (Fig. 5), which is obviously not what would be expected from an upwelling intensification. In order to elucidate the processes underlying the observed SST and SSS patterns, we therefore had to carry out a more in-depth analysis of the forcing.

We first computed the trends in the v-component of the wind (positive pointing to north). This is the wind component responsible for the coastal upwelling and during the upwelling season it is predominantly negative due to the dominant northerly winds. Figure 11 shows some differences in the trends obtained from the two models. In summer HADLEY-low shows negative 

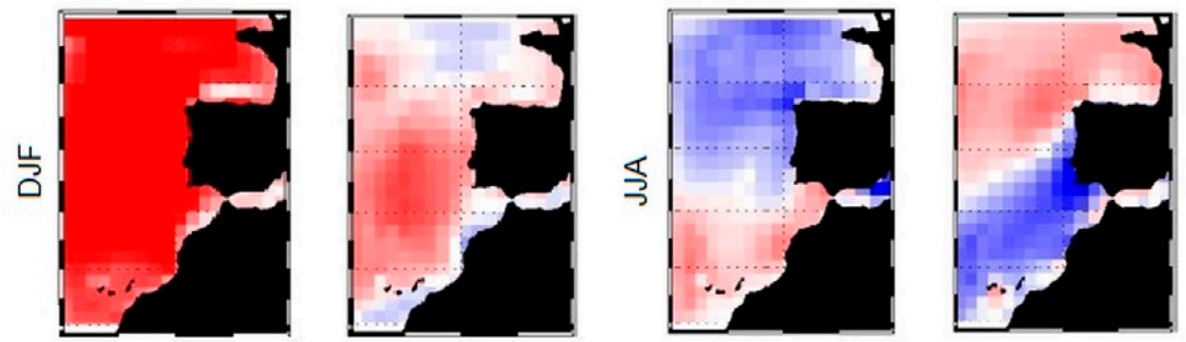

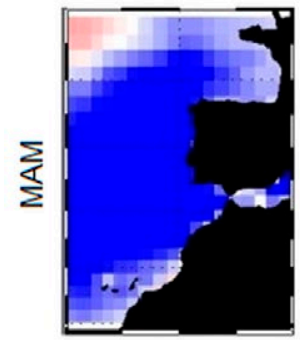

HADLEY-Iow

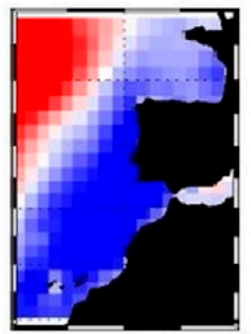

ECHAM

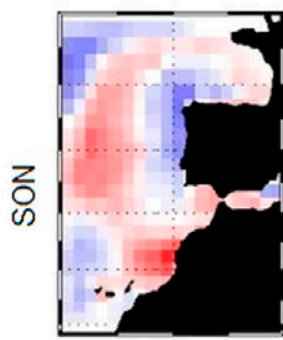

HADLEY-Iow

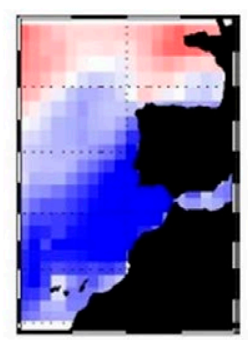

ECHAM
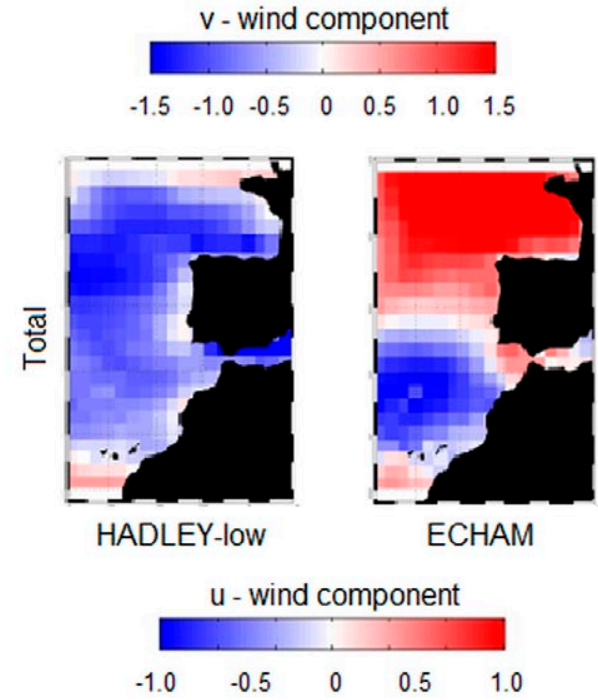

Fig. 11. - (Upper panel) Seasonal trends of the v-component of the wind (pointing to N). The seasons are denoted by DJF (winter), MAM (spring), JJA (summer) and SON (autumn). (Lower panel) Total trends of the u-component of the wind (pointing to E). All trends are computed from the HADLEY-low and ECHAM projections (2001-2050) and are statistically significant (at the 95\% confidence level) all over the domain. Units are $(\mathrm{cm} / \mathrm{s}) / \mathrm{y}$.

trends (that is, increasing northerly winds and more upwelling) all along the Iberian margin, particularly in its northern sector. It also shows slightly positive trends (weaker northerly winds and therefore less upwelling) along the African coasts; however, it must be noted that trends are markedly negative all over the domain in spring, which may explain why the overall effect is a slight enhancement of the upwelling also along the African coast. ECHAM also shows negative summer trends along the Iberian margin, which are more intense below approximately $40^{\circ}$ latitude. Along the African coast ECHAM shows slightly negative trends in summer, preceded again by markedly negative trends in spring. These findings suggest a future enhancement of the upwelling system, more intense along the Iberian margin and less intense along the African coasts. It is worth noting that the impact of the enhanced upwelling would not be limited to the upwelling season; the upwelled, cold waters remain at the surface, spreading offshore and contributing to the smoothing of the overall warming of the region all year round (see Fig. 3).

Looking at the u-component of the wind (pointing to the east) is also useful to explain the fate of the upwelled waters. Figure 11 also shows that in the HADLEY-low projection westerly winds decrease all over the domain, while in ECHAM they increase roughly above $40^{\circ}$ latitude and decrease to the south. In the case of HADLEY-low the weakening of the westerlies would favour the exportation of upwelled waters offshore; in ECHAM this would also happen below $40^{\circ}$, but above that latitude the strengthening of the westerlies would favour the piling of the waters against the coast. This explains the shape of the SST trends obtained for each model (Fig. 3).

The hypothesized enhancement of the Iberian upwelling must, however, be reconciled with the negative SSS trends projected by both models (more marked in HADLEY-low). The explanation comes from the ad- 
vection of fresh water masses from higher latitudes. Figure S6 shows the decadal SSS changes inferred both from the control simulations and from the projections of both models. In several decades and for both models there is evidence of an increase in the SSS linked to the Iberian upwelling system. However, HADLEY-low also shows fresh waters entering the domain from the north by 2010 and occupying most of the northern half of the domain by 2020 . This fresh water occupies the upper $200 \mathrm{~m}$ of the water column (not shown), completely hiding any upwelling signal from then on and being responsible for the marked negative SSS trends observed in Figure 5. At lower latitudes the advection is mainly from the west, and the water masses entering the domain since 2000 have relatively high salinity and occupy the upper 300-400 m of the water column (not shown). The upwelling signal is also hidden by advection in the ECHAM simulations, though in that case the salinity is not as low as for HADLEY-low and the advected water masses come from the west and south by 2010-19 and from the north later on (Fig. S6).

The key point is that in both models the salinity decrease due to advection is fairly large and affects at least the first $200 \mathrm{~m}$ of the water column. This implies that the water upwelled in the future will be fresher than present surface waters, resulting in the observed overall negative SSS trends. The water mass entering the domain from the north in HADLEY-low, for instance, is about $1 \mathrm{psu}$ fresher than resident waters, while the difference between the surface and subsurface layers in the upwelling region is about 0.5 psu. This means that in spite of the increase in the amount of upwelled water projected for the 21 st century, the salinity of the surface layer will be lower than at present.

\section{On the physical processes related to the SST and SSS projections}

The projected enhancement of the Iberian coastal upwelling is obviously related to an increase in the northerly winds. In fact, some of the previous works hypothesizing this enhancement are based only on the wind increase inferred from climate models, while others use an ORCM to model the changes. Among the latter, Miranda et al. (2012) used an ORCM with a $1 / 12^{\circ}$ resolution forced with a dynamical downscaling of the HadCM2 global model run under the A2 scenario. They obtained an enhancement of the coastal upwelling (more frequent events with higher intensity) in the northern sector of the Iberian margin, near Cape Finisterre. They also showed that upwelled waters can be exported offshore for a few hundred kilometres and that they are able to locally cancel the effect of global warming in terms of SST trends. The difference from our work is that Miranda et al. (2012) is a process-oriented study rather than a climate projection, so they used climatological (constant) values at the open boundaries of the ORCM. This obviously prevents the advection of remote water masses into the domain and hence the masking of the upwelling enhancement, as happens in our projections. Another process-oriented study is the one by Cordeiro-Pires
(2013), who forced an ORCM with the mean wind and surface fluxes obtained from a set of 9 GCMs run under the A2 scenario, again keeping the boundary values of the ORCM constant. These authors obtained an SST increase (for the period 2070-2100 in comparison with $1970-2000)$ of about $1^{\circ} \mathrm{C}$ during the upwelling season (April to September) and of about $2^{\circ} \mathrm{C}$ during the other months.

The decrease in SSS obtained in our work has also been reported in previous studies. Terray et al. (2012) looked at 14 CMIP3 models run under the A1B scenario, reporting for 2100 and our region of interest a decrease of about $-0.1 /-0.2$ psu due to melting of Greenland and Arctic ice. Cordeiro-Pires (2013) obtained a freshening of about -0.2 psu (for the period 2070-2100 in comparison with 1970-2000) from the 9 GCMs used in their study. The values quoted in the IPCC (2013) AR5, obtained from 28 CMIP models run under the RCP8.5 scenario, range between -0.5 and -1 psu (again for 2100 and our region of interest). A feature worth noting is that beyond the mean trends reported, all studies show large discrepancies between models (e.g. from -1 to +0.4 psu in Terray et al. 2012), which is consistent with the marked differences observed here between HADLEY-low and ECHAM. The large uncertainties are due to both discrepancies in the amount of melted ice and differences in the evolution of the large-scale circulation in the North Atlantic.

The importance of the discrepancies obtained for the evolution of SSS goes beyond the Atlantic domain, as these waters are the ones entering the Mediterranean Sea through the Strait of Gibraltar. It is worth commenting here that all climate projections point to drier and warmer conditions over the Mediterranean, which would result in a saltier basin assuming that the Atlantic waters entering through Gibraltar were the same (or saltier) than at present. However, if these waters were significantly fresher in the future, as the two models used here seem to suggest, they could partially counteract the forcing of the local heat and freshwater fluxes and result in a slowing down of the salinization of the Mediterranean or even in a freshening (see e.g. Gualdi et al. 2011). Moreover, it must be noted that the projected increase in the E-P+R budget of the Mediterranean (the process leading the long-term variability of Gibraltar fluxes, see e.g. Boutov et al. 2014) will result in an increase in the net flux through Gibraltar, which would enhance the impact of Atlantic waters on the Mediterranean circulation.

Conversely, changes in the salinity of the Mediterranean could also have an impact on the Atlantic circulation: salinity controls the buoyancy of the Mediterranean outflow in the Atlantic and therefore affects its interaction with the shallow-intermediate circulation that drives the surface climate. Ivanovic et al. (2014) have shown that changing Mediterranean salinity by a factor of two would result in a reorganization of the shallow North Atlantic circulation and in regional climate anomalies of $\pm 4^{\circ} \mathrm{C}$ or more. However, although such major variations in salinity are believed to have occurred in the past, our (and all other) future projec- 
tions are very far from these values. That is, although changes in the Mediterranean's hydrological balance can have impact on the North Atlantic, these are envisaged to be small (Ivanovic et al. 2014).

\section{On sea level projections}

The total sea level trends obtained (excluding the mass component) are up to $4 \mathrm{~mm} / \mathrm{y}$ during the period 2000-2050 (Fig. 7), with a spatially averaged value of $1.4 / 2.2 \mathrm{~mm} / \mathrm{y}$ for the ECHAM/HADLEY-low simulations. In comparison with recently published estimates, these numbers are small. For example, Slangen et al. (2014) obtained $\sim 2.5 \mathrm{~mm} / \mathrm{y}$ and $\sim 4 \mathrm{~mm} / \mathrm{y}$ for the whole 21 st century and our region of interest under the RCP4.5 and RCP8.5 climate scenarios, respectively. Our A1B scenario is similar to RCP6.0, so our results should be between these two values.

The first reason for the possible underestimation of sea level trends could be the shorter period considered in our work (only the first half of the 21 st century), because most models spanning the next 100 years show that sea level rise will accelerate from 2050 onwards. A second and perhaps more important reason is that the baroclinic ORCM used in our work cannot account for mass redistribution in and out of the considered domain, since the boundaries are rigid in terms of sea level. This is particularly important in regions where global models show noticeable sea level variations due to large-scale circulation changes. This is precisely the case of the NE Atlantic, where sea level rise projections are shown to exceed global mean sea level rise by $15 \mathrm{~cm}$ in 2050 and $35 \mathrm{~cm}$ by 2100 (Landerer et al. 2014). A third source of discrepancy may come from the fact that we use only two models: the large spread of results shown by the ensemble of GCMs suggests that single-model results must be associated with a large uncertainty for both present-day assessments (Landerer et al. 2014) and future projections (Little et al. 2015). Finally, it is worth recalling that the trends reported here for total sea level do not account for changes in the ocean water mass content due to the melting of continental ice. The amount of this missing component is also very uncertain, ranging from the 1.2 $\mathrm{cm} /$ decade reported in the IPCC AR4 (see for instance Meehl et al. 2007) to the $4.6 \mathrm{~cm} /$ decade of more recent estimates (see e.g. Bamber and Aspinall 2013).

It is important to note that the limitations of our study are common to all ORCMs. Only very recently and thanks to the clarifying works of Calafat et al. (2012) and Jordà and Gomis (2013), some ORCMs have started to use sea level from a GCM as a boundary condition. Hopefully, this crucial handicap to diagnosing sea level will be overcome in the next generation of ORCMs. Meanwhile, ORCM sea level estimates must be complemented with sea level regional anomalies (with respect to GMSL) inferred from GCMs. The uncertainty associated with the contribution of ice melting affects both ORCMs and GCMs. That is, our work shares the same limitations as others, and the only way of reducing this uncertainty is to improve the understanding of the ice-related processes.
Conversely, none of the two handicaps quoted for mean sea level (rigid boundaries and uncertainty of the ice melting contribution) affect our results on sea level extremes, since these are mainly due to the atmospheric (barotropic) component. We have shown that the meteorological tide will suffer very small changes, indicating that extreme sea levels will be higher in the 21 st century but only due to the increase in mean sea level, not due to the storminess. The physical processes underlying the barotropic component of sea level will not be addressed here, as they have already been discussed both for the mean regime (Jordà et al. 2012) and for the extreme events (Marcos et al. 2011) under different climate change scenarios.

\section{On wave projections}

Regarding wave projections, for 2100 and under the A1B scenario ECHAM has shown a decrease in annual $\mathrm{SWH}$ values of $-0.19 \mathrm{~cm} /$ year $(-10 \%)$ when averaged over the whole domain (Table 9). This value is similar to the one obtained by Hemer et al. (2012), who also used the ECHAM climate model to obtain a dynamical wind-wave global simulation but under the A2 emission scenario. More precisely, they also obtained a decrease of 10\% for the period 1979-2099 and for the Atlantic coasts of the Iberian Peninsula. Significantly smaller changes in annual SWH have been projected by HADLEY-low (1\%), HADLEY-ref $(-3 \%)$ and HADLEY-high $(-2 \%)$. These differences reflect the uncertainty associated with the winds projected by different climate models, as recently shown by Hemer et al. (2013) from a large ensemble of global wave simulations based on CMIP3 climate models. That is, our results point towards slightly smaller SWH, but the changes projected for 2100 are of the same order as the natural variability. The physical processes underlying the variability of the wave climate in the North Atlantic will not be addressed here, as they have already been discussed in Martínez-Asensio et al. (2015a, 2015b).

\section{CONCLUSIONS}

We have presented an overall view of the changes expected in key marine parameters in the sector of the NE Atlantic Ocean close to the Spanish shores. Because our aim is not only to report the projected changes but also to generate useful products for coastal managers, harbour authorities and other stakeholders, all data sets used in this work are, or will be, available for public use (e.g. in http://marine-climate.uib.es/). The changes described in this study can be summarized as follows.

In the open sea and under the scenario A1B the SST will increase by $1^{\circ} \mathrm{C}$ to $1.5^{\circ} \mathrm{C}$ by 2050 , as a consequence of the global ocean warming. Near the continental margin, however, the global temperature rise could be counteracted by an enhancement of the seasonal upwelling. Along the Iberian margin the enhancement could be strong enough to result in negative temperature trends of the order of $-0.2^{\circ} \mathrm{C} /$ decade, while along the African coast it would only result in a reduction of the open-sea positive temperature trends. The impact 
of the enhanced upwelling will not be limited to the upwelling season: the upwelled, cold waters will remain at the surface, spreading offshore and contributing to the smoothing of the overall warming of the region all year round.

SSS is likely to decrease in the future, mainly due to the advection of high-latitude fresher waters from ice melting. The advection could hide the SSS trace of the enhanced upwelling, since the difference between the salinity of the advected waters and resident waters could be higher than the difference between surface and subsurface salinity (this is not the case for SST, for which the difference between surface and subsurface temperatures is higher than the global warming, so the enhanced upwelling may even result in negative SST trends). However, our models and also the results reported in previous works show a large degree of uncertainty in the magnitude of the freshening due to discrepancies in the amount of melted ice and in the large-scale circulation of the North Atlantic. The importance of these discrepancies goes beyond the Atlantic domain, as these waters can have a strong influence on the evolution of the salinity within the Mediterranean basin.

Mean sea level rise (excluding the ice melting) has been estimated at $15-20 \mathrm{~cm}$ by 2050 . This estimate must be complemented with the mass redistribution derived from changes in the large-scale circulation (not accounted for by the ORCM). In the NE Atlantic this contribution may be as large as $15 \mathrm{~cm}$ in 2050 (35 $\mathrm{cm}$ by 2100$)$, as shown by GCMs. The increase in the ocean mass content due to the melting of continental ice is also to be added to our trends; the estimates of the latter are rather uncertain (from 1 to more than $4 \mathrm{~cm} /$ decade), but they are envisaged as a major component of sea level rise. The results for extreme sea levels are more robust than those for mean sea level in the sense of pointing to very slight changes in the meteorological tide. That is, extreme sea levels will be higher in the 21 st century, but only due to the increase in mean sea level, not to an increase in the storminess.

The wave projections point towards slightly smaller SWH, but the changes projected for 2100 are of the same order as the natural variability. Within the small range obtained from the trends (decreases of less than $10 \%$ ) the models show discrepancies that reflect the uncertainty associated with the winds projected by different climate models.

\section{ACKNOWLEDGEMENTS}

The computational work of this paper was carried out in the framework of two projects: VANIMEDAT-2 (CTM2009-10163-C02-01), funded by the Spanish Ministerio de Economía y Competitividad (MINECO) and the E-Plan of the Spanish Government; and ESCENARIOS, funded by the Agencia Estatal de Meteorología (AEMET). Some of the analysis and summary efforts were carried out in the framework of the subsequent project CLIMPACT (CGL2014-54246-C2-1-R), also funded by MINECO. In particular, the contracts of A. Martínez-Asensio and J. Llasses are funded by these projects. M. Marcos and G. Jordà acknowledge their respective Ramón y Cajal contracts funded by the Spanish Ministry of Economy and the Regional Government of the Balearic Islands.

\section{REFERENCES}

Adloff F., Somot S., Sevault F., et al. 2015. Mediterranean Sea response to climate change in an ensemble of twenty first century scenarios. Clim. Dyn. 45 (9): 2775-2802 http://dx.doi.org/10.1007/s00382-015-2507-3

Álvarez I., Gomez-Gesteira M., De Castro M., et al. 2008. Spatiotemporal evolution of upwelling regime along the western coast of the Iberian Peninsula. J. Geophys. Res. 113: C07020. http://dx.doi.org/10.1029/2008JC004744

Álvarez-Fanjul E., Pérez B., Rodríguez I. 2001. NIVMAR: A storm-surge forecasting system for Spanish waters. Sci. Mar. 60: $145-154$ http://dx.doi.org/10.3989/scimar.2001.65s1145

Alves J.M.R., Miranda P.M.A. 2013. Variability of Iberian upwelling implied by ERA-40 and ERA-Interim reanalyses. Tellus A. 65: 19245. http://dx.doi.org/10.3402/tellusa.v65i0.19245

Backhaus J.O. 1985. A Three-Dimensional model for simulation of shelf sea dynamics. Dt. Hydrogr. Z. 38: 164-187. http://dx.doi.org/10.1007/BF02328975

Bamber J.L., Aspinall W.P. 2013. An expert judgement assessment of future sea level rise from the ice sheets. Nature Clim. Change 3: 424-427. http://dx.doi.org/10.1038/nclimate 1778

Barnier B. 1998. Forcing the ocean, in ocean modeling and parameterisation. In: Chassignet E.P., Verron J. (eds), NATO Sciences Series, vol. 516. Kluwer Academic Publishers, pp. 45-80.

Bopp L., Resplandy L., Orr J.C., et al. 2013. Multiple stressors of ocean ecosystems in the 21st century: projections with CMIP5 models. Biogeosci. 10: 6225-6245. http://dx.doi.org/10.5194/bg-10-6225-2013

Bourdallé R., Treguier A.M. 2006. A climatology of run-off for the global ocean-ice model ORCA025. Mercator-Ocean reference: MOO-RP-425-365-MER, August 2006.

Boutov D., Peliz A., Miranda P.M.A., et al. 2014. Inter-annual variability and long term predictability of exchanges through the Strait of Gibraltar. Global Planet. Change 114: 23-37. http://dx.doi.org/10.1016/j.gloplacha.2013.12.009

Calafat F.M., Jordà G., Marcos M., et al. 2012. Comparison of Mediterranean sea level variability as given by three baroclinic models. J. Geophys. Res. 117: C02009. http://dx.doi.org/10.1029/2011JC007277

Cordeiro Pires A., Nolasco R., Rocha A., et al. 2013. Assessing future climate change in the Iberian Upwelling System. Proceedings of the 12th International Coastal Symposium (Plymouth, England), J. Coast. Res., Special Issue No. 65: 1909-1914, ISSN 0749-0208.

Dee D.P., Uppala S.M., Simmons A.J., et al. 2011. The ERAInterim reanalysis: Configuration and performance of the data assimilation system. Quart. J. R. Meteorol. Soc. 137: 553-597. http://dx.doi.org/10.1002/qj.828

Griffies S.M., Greatbatch R.J. 2012. Physical processes that impact the evolution of global mean sea level in ocean climate models. Ocean Model. 51: 37-72. http://dx.doi.org/10.1016/j.ocemod.2012.04.003

Gualdi S. et al. 2011. Future Climate Projections, In: Navarra A. and Tubiana L. (eds), Regional Assessment of Climate Change in the Mediterranean, Springer, Dordrecht, The Netherlands.

Günther H., Hasselman S., Jansen P.A.E. 1992. The WAM model cycle, 4 (revised version). Technical Report 4, Deutsches Klimarechenzentrum (DKRZ), Hamburg, Germany.

Hemer M.A., Katzfey J., Trenham C. 2012. Global dynamical projections of surface ocean wave climate for a future high greenhouse gas emission scenario. Ocean Model. 70: 221-245. http://dx.doi.org/10.1016/j.ocemod.2012.09.008

Hemer M.A., Fan Y., Mori N., et al. 2013. Projected changes in wave climate from a multi-model ensemble. Nature Clim. Change 3: 471-476. http://dx.doi.org/10.1038/nclimate1791

Ishii M., Kimoto M. 2009. Reevaluation of Historical Ocean Heat Content Variations with Time-Varying XBT and MBT Depth Bias Corrections. J. Oceanogr. 65: 287-299. 
http://dx.doi.org/10.1007/s10872-009-0027-7

IPCC (Intergovernmental Panel on Climate Change). 2013. Climate change 2013: The physical science basis. Working Group I contribution to the IPCC Fifth Assessment Report. Cambridge Univ. Press, UK.

www.ipcc.ch/report/ar5/wg 1

Ivanovic R.F., Valdes P.J., Gregoire L., et al. 2014. Sensitivity of modern climate to the presence, strength and salinity of Mediterranean-Atlantic exchange in a global general circulation model. Clim. Dyn. 42: 859-877. http://dx.doi.org/10.1007/s00382-013-1680-5

Jordà G., Gomis D. 2013. On the interpretation of the steric and mass components of sea level variability. The case of the Mediterranean basin. J. Geophys. Res. 118: 953-963. http://dx.doi.org/10.1002/jgrc.20060

Jordà G., Gomis D., Álvarez-Fanjul E., et al. 2012. Atmospheric contribution to Mediterranean and nearby Atlantic sea level variability under different climate change scenarios. Global Planet. Change, 80-81: 198-214. http://dx.doi.org/10.1016/j.gloplacha.2011.10.013

Jones C.G., Willen U., Ullerstig A., et al. 2004. The Rossby Centre Regional Atmospheric Climate Model part I: model climatology and performance for the present climate over Europe. Ambio, 33: 199-210. http://dx.doi.org/10.1579/0044-7447-33.4.199

Landerer F.W., Gleckler P.J., Lee T. 2014. Evaluation of CMIP5 dynamic sea surface height multi-model simulations against satellite observations. Clim. Dyn. 43: 1271-1283. http://dx.doi.org/10.1007/s00382-013-1939-x

Lebeaupin-Brossier C., Bérangerr K., Deltel C., et al. 2011. The Mediterranean response to different space-time resolution atmospheric forcings using perpetual mode sensitivity simulations. Ocean Model. 36: 1-25. http://dx.doi.org/10.1016/j.ocemod.2010.10.008

Levitus S., Boyer T. P. 1994. World Ocean Atlas, Volume 4: Temperature. NOAA Atlas NESDIS 4, U.S. Department of Commerce, Washington D.C., 117 pp.

Levitus S., Burgett R., Boyer T.P. 1994. World Ocean Atlas, Volume 3: Salinity. NOAA Atlas NESDIS 3, U.S. Department of Commerce, Washington D.C., 99 pp.

Little C.M., Horton R.M., Kopp R.E., et al. 2015. Uncertainty in Twenty-First-Century CMIP5 Sea Level Projections. J. Climate 28: $838-852$.

http://dx.doi.org/10.1175/JCLI-D-14-00453.1

Lorbacher K., Marsland S.J., Church J.A., et al. 2012. Rapid barotropic sea level rise from ice sheet melting, J. Geophys. Res. 117: C06003. http://dx.doi.org/10.1029/2011JC007733

Madec G. 2008. NEMO ocean engine. Note du Pole de modélisation, Institut Pierre-Simon Laplace (IPSL), France, No. 27, ISSN No. 1288-1619.

Marcos M., Jordà G., Gomis D., et al. 2011. Changes in storm surges in southern Europe from a regional model under climate change scenarios. Global Planet. Change 77: 116-128. http://dx.doi.org/10.1016/j.gloplacha.2011.04.002

Martínez-Asensio A., Tsimplis M.N., Marcos M., et al. 2015a. Response of the North Atlantic wave climate to atmospheric modes of variability. Int. J. Climatol. In press. http://dx.doi.org/10.1002/joc.4415

Martínez-Asensio A., Marcos M., Tsimplis M.N., et al. 2015b. On the ability of statistical wind-wave models to capture the variability and long-term trends of the North Atlantic winter wave climate. Ocean Model. (in press).

Meehl G.A., Stocker T.F., Collins W., et al. 2007. Global climate projections. In: Solomon S., Qin D., Manning M. (eds), Climate change 2007: the physical science basis. Contribution of working group 1 to the fourth assessment report of the intergovernmental panel on climate change. Cambridge Univ. Press, Cambridge.

Miranda P.M.A., Alves J.M.R., Serra N. 2012. Climate change and upwelling: response of Iberian upwelling to atmospheric forcing in a regional climate scenario. Clim. Dyn. 40(11): 2813-2824. http://dx.doi.org/10.1007/s00382-012-1442-9

Pope V.D., Gallani M.L., Rowntree P.R., et al. 2000. The impact of new physical parametrizations in the Hadley Centre climate model - HadAM3. Clim. Dyn. 16: 123-146. http://dx.doi.org/10.1007/s003820050009
Relvas P., Luis J., Santos A.M.P. 2009. Decadal changes in the Canary system. Geophys. Res. Lett. 36, L22601. http://dx.doi.org/10.1029/2009GL040504

Roeckner E., Bauml G., Bonaventura L., et al. 2003. The atmospheric general circulation model ECHAM 5. Part I: model description. Technical Report 349, Max Planck Institute for Meteorology.

Samuelsson P., Jones C.G., Willen U., et al. 2011. The Rossby Centre regional model RCA3: Model description and performance. Tellus A 63: 4-23. http://dx.doi.org/10.1111/j.1600-0870.2010.00478.x

Slangen A.B.A., Carson M., Katsman C.A., et al. 2014. Projecting twenty-first century regional sea-level changes. Climatic Change 124: 317-332. http://dx.doi.org/10.1007/s10584-014-1080-9

Soto-Navarro J., Somot S., Sevault F., et al. 2014. Evaluation of regional ocean circulation models for the Mediterranean Sea at the strait of Gibraltar: volume transport and thermohaline properties of the outflow. Clim. Dyn. 44: 1277-1292. http://dx.doi.org/10.1007/s00382-014-2179-4

Terray L., Corre L., Cravatte S., et al. 2012. Near-Surface Salinity as Nature's Rain Gauge to Detect Human Influence on the Tropical Water Cycle. J. Climate 25: 958-977. http://dx.doi.org/10.1175/JCLI-D-10-05025.1

Uppala S.M., Kallberg P.W., Simmons A.J., et al. 2005. The ERA40 re-analysis. Quart. J. R. Meteorol. Soc. 131: 2961-3012. http://dx.doi.org/10.1256/qj.04.176

Vörösmarty C., Fekete B., Tucker B. 1998. Global river discharge, 1807-1991, v. 1.1 RivDIS Data set, http://www.daacornl.gov from Oak Ridge National Laboratory Distributed Active Archive Center, Oak Ridge, TN, USA.

WAMDI Group. 1988. The WAM model - a third generation ocean wave prediction model. J. Phys. Oceanogr. 18: 1775-1810. http://dx.doi.org/10.1175/1520-0485(1988)018<1775:TWMT $\mathrm{GO}>2.0 . \mathrm{CO} ; 2$

\section{SUPPLEMENTARY MATERIAL}

The following material is available through the online version of this article and at the following link:

http://www.icm.csic.es/scimar/supplm/sm04328esm.pdf

Fig. S1. - Differences between the hindcast forced with the downcalling of ERA-40 and the Ishii climatology for the period 1961-2000. The figures show the differences between the mean values and the standard deviation (variability) for SST and for SSS.

Fig. S2. - Comparison of the SST measured by the buoy located offshore of Cabo Silleiro (at $42.12^{\circ} \mathrm{N} 09.43^{\circ} \mathrm{W}$, over a depth of $600 \mathrm{~m}$ ) with the values of the closest grid point of the hindcasts forced with ERA40 and ERA-Interim.

Fig. S3. - SST seasonal cycle averaged over the whole domain obtained from the hindcast forced with ERA40 (1971-2000, in black), the control simulations forced with HADLEY-low and ECHAM (1971-2000, blue and red dashed lines, respectively) and forced with the A1B scenarios of HADLEY-low and ECHAM (2021-2050, continuous blue and red lines, respectively).

Fig. S4. - Baroclinic sea level seasonal means of the hindcast forced with ERA40 and of the control simulations forced with HADLEY-low and ECHAM for the common period 1961-2000. The seasons are denoted by DJF (winter), MAM (spring), JJA (summer) and SON (autumn). Units are $\mathrm{cm}$.

Fig. S5. - Barotropic sea level seasonal means of the hindcast forced with ERA40 and of the control simulations forced with ECHAM, HADLEY-low, HADLEY-ref and HADLEY-high for the common period 1961-2000. The seasons are denoted by DJF (winter), MAM (spring), JJA (summer) and SON (autumn). Units are $\mathrm{cm}$.

Fig. S6. - Decadal evolution of SSS: each plot shows the time-mean change during the reported period as inferred from the control simulations (decades 1961-1969, 1970-79, 1980-89 and 199099 ) and from the projections (decades 2000-09, 2010-19, 202029, 2030-39 and 2040-49) of HADLEY-low and ECHAM. Units are psu. 